\title{
The Project of Air Pollution Awareness: Interdisciplinary Community
} Service Practices

\author{
Funda AYDIN GÜç*, Müge AYGÜN*๋ ${ }^{* \dagger}$ Derya CEYLAN*, Seda ÇAVUŞ GÜNGÖREN*, \\ Ümmü Gülsüm DURUKAN", Yasemin HACIOĞLU*, Ayşe Dilek YEKELER*
}

Giresun Üniversitesi Eğitim Fakültesi, Giresun/Türkiye

\section{Article Info}

DOI: $10.14812 /$ cufej.309435

Keywords:

Interdisciplinary approach,

Air pollution awareness,

Community service practices

course.

\begin{abstract}
The aim of this research is to introduce an interdisciplinary project about air pollution that is organized and applied for Community Service Practice Course. In order to organize this project 32 pre-service primary school teachers and 120 students' awareness toward air pollution (4th grade) have been determined through The Air Pollution Awareness Questionnaire. The results obtained from the needs analysis indicate that learning environments need to be designed that focus on fundamental concepts, causes-effects, future situation and precautions in order to increase air pollution awareness. To achieve an interdisciplinary approach, a two stage learning environment has been designed by relating these focus points with Turkish, Social Studies, Science, Mathematics and Public Administration disciplines respectively. These two stages are preparing the discipline-based course plans and materials; and carrying out the interdisciplinary plans with students by pre-service teachers. In this article, the design, development and implementation process of this learning environment are presented in detail. As a result of this research, a roadmap for how to deal with the Community Service Practices Course in an interdisciplinary manner has been established.
\end{abstract}

\section{Hava Kirliliği Farkındalığı Geliştirme Projesi: Disiplinlerarası Topluma Hizmet Uygulamaları}

\section{Makale Bilgisi}

DOI: $10.14812 /$ cufej.309435

\section{Öz}

Bu çalışmanın amacı Topluma Hizmet Uygulamaları Dersi kapsamında yürütülen hava kirliliğiyle ilgili disiplinlerarası bir projeyi tanıtmaktır. Bu projeyi planlayabilmek için 32 sınıf öğretmeni adayı ve 120 öğrencinin (4. sınıf) farkındalıkları Hava Kirliliği Farkındalık Anketiyle belirlenmiştir. Intiyaç analizinden elde edilen bulgular hava kirliliği farkındalığını geliştirebilmek için temel kavramlar, nedenler-sonuçlar, gelecekteki durum ve önlemler odaklarında öğrenme ortamlarının tasarlanması gerektiğini ortaya koymuştur. Disiplinlerarası bir yaklaşım için bu odaklar sırasıyla Türkçe, Sosyal, Fen, Matematik ve Kamu Yönetimi disiplinleriyle ilişkilendirilerek iki aşamalı bir öğrenme ortamı tasarlanmıştır. Bu aşamalar disipline dayalı ders planlarının ve materyallerinin hazırlanması ve planların disiplinlerarası olarak öğretmen adaylarınca öğrencilere uygulanması şeklindedir. Bu çalışmada da bu öğrenme ortamının tasarımı, geliştirilmesi ve uygulanması ayrıntııı şekilde tanıtılmışır. Yapılan çalışmada sonuç olarak Topluma Hizmet Uygulamaları Dersinin disiplinlerarası olarak nasıl işlenebileceğine dair bir yol
Anahtar Kelimeler:

Disiplinlerarası yaklaşım,

Hava kirliliği farkındalığı,

Topluma hizmet uygulamaları dersi

All authors contributed equally to this study and listed in alphabetical order.

†'Author:mgkpnr@gmail.com 


\section{Introduction}

Teachers are the most important element of the education system that affects the society. Due to their roles and responsibilities such as integrating with the society, being a leader in the society; teachers should receive necessary training that empowers these qualities before they begin their profession. It is also essential that they acquire enough experience during these trainings (Çetin \& Sönmez, 2009). Community Service Practices Course (CSPC), which is a mandatory course taught in the departments of education throughout the universities in Turkey, is a medium in which teachers can acquire these experiences (Gökçe, 2012). Similar practices also exist in various other countries and these courses are not only conducted within the scope of teacher education (Beldağ, Yaylacı, Gök \& İpek, 2015). For example, there is a program named Service-Learning in the United States that include all students from K-12 to university (Barton, 2000). Service Learning is based on the importance of "experience" as given by John Dewey (Giles \& Eyler, 1994; You \& Rud, 2010). Within the scope of teacher education, Service Learning is regarded as acquiring experience on complex social problems, developing social skills, and familiarizing with social culture and values by pre-service and in-service teachers (Barton, 2000).

CSPC includes participation as speakers or organizers in scientific events such as seminars, panels etc. about the importance of community service, determining the social problems, designing projects for the purpose of solving these problems, and social issues (Council of Higher Education [CoHH], 2006). This course aims not only to increase the knowledge of future teachers about social issues, but also to ensure they realize the importance of their profession for social development (Gökçe, 2012). In addition, acquiring basic knowledge and skills on how to actualize the community service practices with their students while performing their future professions are also part of the goals of the course (Küçükoğlu, 2012; Özdemir \& Tokcan, 2010).

In order to achieve the goals set by CSPC, the course plans should have an institutionalized structure, implementation and evaluation processes should be organized in accordance with educational programs, and the education environment should be arranged to have multi-stakeholder nature as much as possible (Küçükoğlu, 2012). Some researchers point out to several issues such as planning CSPC, determining the scope, scheduling, and the faculty not being able to provide sufficient guidance (Arcagök \& Şahin, 2013; Gökçe, 2011; Küçükoğlu, Korkmaz, Köse \& Taşgın, 2014). In order to address these issues and achieve the goals of the course, it is vital that the course is well planned and practices with predictable possible outcomes are implemented. There are examples in the literature that determine the opinions of pre-service teachers towards CSPC (Arcagök \& Şahin, 2013; Çetin \& Sönmez, 2009; Gökçe, 2011; Sönmez, 2010), and that evaluates the course in light of these opinions (Ekşi \& Cinoğlu, 2012; Kesten, 2012; Özdemir \& Tokcan, 2010). The impact of implementations within the scope of CSPC on both the pre-service teachers and the target groups which the service is provided should also be investigated. In this respect, revealing the impact of implementations within the scope of CSPC will guide all stakeholders in planning the future implementations.

Implementations within the scope of CSPC start with correct planning and determination of suitable subjects. Subjects such as supporting groups with disadvantage, protecting the environment and product quality can be included within the scope of this course (Yılmaz, 2011). Moreover, additional activities are also carried out such as working together with social service organizations, physically improving various organizations, raising environment and gender awareness (Yılmaz, 2011). A close examination of these activities reveals that they have the goal to generate solutions for social issues. Generally, these kinds of social issues should be handled socio-scientifically (Topçu, 2015), because socio-scientific issues can be resolved by applying knowledge and skills from different disciplines together. For this purpose, in line with the aims of the course, socio-scientific based learning 
environments in which the pre-service teachers and target groups can acquire the knowledge and skills from related disciplines can be established within the scope of CSPC.

Close examination of educational programs also reveal that environment issues are some of the most frequently encountered socio-scientific issues. Raising individuals who are aware of environmental problems and who act against these problems is highly important for the society (Şahin, Cerrah, Saka \& Şahin, 2004). In this respect, pre-service teachers can take active parts in resolving the environmental issues within the scope of CSPC (Gökçe, 2012). Environmental issues span a variety of issues that are encountered within the century we live in such as global warming, climate change, preservation of biological diversity, protecting the health of living beings, and soil, water and air pollution.

There are numerous studies in the literature about the environmental issues. However, it is apparent that these studies generally investigate knowledge, awareness and attitude towards environmental issues (Köklükaya \& Yildirim, 2016; Öztürk, 2002; Şahin, 2013; Şahin, Ertepınar \& Teksöz, 2012), and opinions of individuals educated in various different disciplines are considered in approaching these issues (Demirkaya, 2006; Seçgin, Yalvaç \& Çetin, 2010; Selvi \& Yıldız, 2009). This is because environmental science is classified as an interdisciplinary field, rather than a discipline on its own (Demirkaya, 2006; Yılmaz, Morgil, Aktuğ \& Göbekli, 2002). Air pollution is also an issue that can be resolved by using knowledge and skills from various disciplines together (Uzgören \& Yücel, 1999). This work presents an interdisciplinary project with the theme of air pollution that has been implemented within the scope of CSPC. Before commencing with presenting the project, it is highly helpful to provide a summary of interdisciplinary approach.

\section{Interdisciplinary Approach}

Interdisciplinary approach is a perspective and educational approach where methods from multiple disciplines are deliberately utilized together in order to investigate a theme, problem, issue or event (Jacobs, 1989). Since it correlates and incorporates multiple disciplines under a theme, it is also called thematic approach (İşler, 2004).

There are numerous concepts regarding the use of interdisciplinary approach in learning/ teaching environments such as cooperative, complementary, mixed, integral, participative, system oriented, problem oriented, holistic, multidisciplinary, interdisciplinary and transdisciplinary (Tress, Tress \& Fry, 2005). Smith (2006) associates this diversity of concepts to the individual/educator who takes on the approach and who incorporates the disciplines. Although this situation implies that a different concept can be described for each different implementation, it is apparent that many researchers resort to classification of these concepts (Drake \& Burns, 2004; Fogarty, 1991; Lederman \& Niess, 1997; Petrie, 1992). Most of the classifications used in education include multidisciplinary, interdisciplinary and transdisciplinary approaches.

In the multidisciplinary approach, different disciplines/courses are treated separately with different focus point within the same theme, and knowledge and methods from these disciplines are brought together under this theme (Drake \& Burns, 2004; Grady, 1994). Hence, the focus points chosen in order for the discipline to be learned constitute the theme. Here, while the essential point is learning the discipline, the theme acts as the context in which the disciplines can be learned.

Interdisciplinary approach is the approach where different disciplines and focus points appropriate for disciplines are considered together by way of generating new knowledge or creating cross links, in order for a theme to be learned (Grady, 1994; Tress, Tress \& Fry, 2005, 2007). In this approach, while the essential point is learning the theme, the disciplines have assistive role in understanding different aspects of the theme.

Transdisciplinary approach involves the handling of a specific theme with the participation and viewpoints of various institutes or organizations (e.g. administrators, user groups, general public, etc.) of different disciplines associated with that theme (Tress, Tress \& Fry, 2006). 
Lederman and Niess (1997) use the soup analogy when explaining the difference between interdisciplinary approach and multidisciplinary approach. According to the researchers, multidisciplinary approach resembles "the chicken soup" which is heterogeneous in nature, and the interdisciplinary approach resembles "the tomato soup" where the contents (disciplines) have a homogeneous structure that cannot be distinguished from each other. When a theme is handled with the multidisciplinary approach, it is taught in separate courses independent from each other, and goals/gains of each course are determined separately. On the other hand, when a theme is handled with interdisciplinary approach, it is handled based on the gains of the disciplines/courses associated with the focus points for learning the said theme, and hence the disciplines are not treated separately. Finally, transdisciplinary approach resembles interdisciplinary approach in this respect. The main difference between these two approaches is that in transdisciplinary approach, the theme in question is adapted to real life, and a product is put forth accordingly.

\section{The Importance and the Aim of the Project}

Various studies indicate that students and teachers have low level of knowledge on the subject of air pollution and lack the scientific perspective (Boyes, Stanisstreet \& Yeung 2004; Darçın \& Sert-Çıbık, 2009; Thornber, Stanisstreet \& Boyes, 1999). However, increasing the level of knowledge and awareness of individuals is highly essential for the solution of problems related to air pollution (Demirbaş \& Pektaş, 2009). Teachers have the most responsibility after the families, about raising the individuals in the society. Therefore, teachers should be able to determine the problems related to socio-scientific issues, and be able to raise individuals with awareness by organizing activities to increase the consciousness of the people (Seçgin, Yalvaç \& Çetin, 2010). In this respect, it is important that activities with community service contents are included in the education of teachers, and the pre-service teachers acquire experience on community service. Hence, it is thought that when they become teachers, they can be ready to determine the problems in the school and its surrounding environment, and take the necessary actions in order to solve these problems by making use of their existing experiences.

In order for the studies on socio-scientific issues such as air pollution to transcend the act of only providing information and to be handled with the aspect of raising awareness, activities involving implementations should be carried out (Önal \& Güngördü, 2008). In order to achieve this goal, it is important to design learning environments where the pre-service teachers can gain experience on how to handle the socio-scientific issues with interdisciplinary approach. One of the courses where these learning environments can be designed is CSPC which has objectives such as "identify current problems of the society and prepare projects to solve" and "to gain basic knowledge and skills for the implementation of community service work in schools" (CoHE, 2006).

In this project, the pre-service teachers are considered to gain professional experience about air pollution awareness, as well as interdisciplinary education. It is essential that the pre-service teachers raise awareness in their future students by utilizing these gains they acquire. It is hoped that the activities performed within the scope of this project not only enable raising awareness in the students but also in larger groups with a flow from the students to their families and from the families to the community. In this respect, the pre-teachers are provided an opportunity to transfer the knowledge and awareness they gain to their prospective students within the scope of the project that aims to create suitable contents in accordance with the objectives of CSPC. Hence it is important that the impact of the activities carried out under the scope of the project is investigated for both the students and the preservice students. Moreover, this study is considered to provide guidance for the academics that will develop contents for CSPC and for teachers and faculty members who will conduct community services or teach courses with the interdisciplinary approach. In this context, the purpose of this research is to introduce an interdisciplinary project that is organized and applied about air pollution in CSPC. 


\section{Project Design, Development and Implementation Process}

The flowchart that indicates the process followed for the design, development and implementation of the project, and the activities conducted for each step of the process is presented in Figure 1.

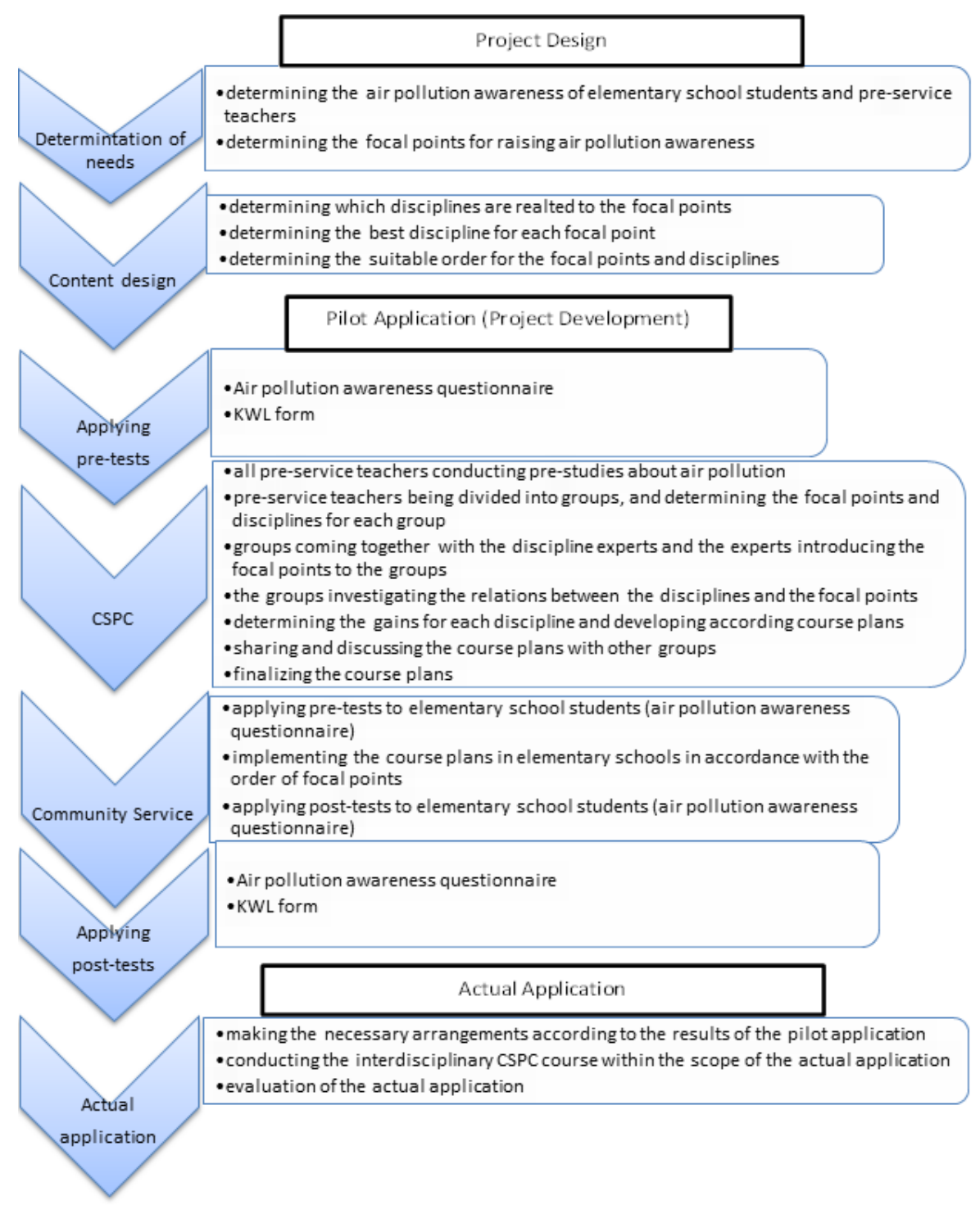

Figure 1.The flowchart indicating the activities conducted during the design and implementation of the project

As seen in Figure 1, the need analysis was conducted primarily to determine the current awareness of students and pre-service teachers about air pollution and the awareness that needs to be improved. Following this analysis, an interdisciplinary approach is adopted and a learning environment is designed. The pilot implementation of the designed learning environment was evaluated by comparing the pretest and post-test results. Following the pilot implementation, the main implementation was carried out and the evaluation was carried out again by comparing the results of the pre-test and post-test. 
The researchers acted as both researchers and discipline experts during the design, development and implementation processes of the project. The activities performed during the project are introduced in the following chapters in accordance with the flowchart.

\section{Project Design}

During the designing stage of the project, first, the needs analysis has been performed in order to determine the important focus points for raising air pollution awareness. For this purpose, Air Pollution Awareness Questionnaire (APAQ) prepared by the researchers has been applied on 32 pre-service primary school teachers and 120 fourth grade primary school students (Table 1). The group in which these pre-service teachers are located was randomly selected from the four groups attending CSPC classes at an education faculty. On the other hand, students are educated in four schools selected randomly from primary schools in the same city so that the pre-service teachers can reach the CSPC course implementation process. Four common questions related to the description of air pollution, reasons, results and actions to take in order to prevent pollution have been asked with APAQ to both pre-service teachers and fourth grade students. Additionally, pre-service teachers have been asked four more questions about the national and international sanctions against air pollution, whether there is air pollution in the city they reside in, how this pollution affects their lives, and what do they do or want to do in order to prevent air pollution. The students have been asked fewer questions than the pre-service teachers, because it is considered that due to their development level, the students can become bored with the long questionnaire and can leave the questionnaire incomplete. Opinions were obtained from two researchers who were experts in the field of Primary School Teaching for the questionnaires prepared. The questions were determined according to the cognitive development levels of the students and the pre-service teachers in line with experts' opinions (Table 1).

Table 1.

Questions in the APAQ Used for Needs Analysis, Their Purposes, and Groups whom are Asked the Questions.

\begin{tabular}{|c|c|c|}
\hline Question & Purpose & Group \\
\hline What do you think the air pollution is? & $\begin{array}{l}\text { Determining the air pollution } \\
\text { awareness with a general point of view }\end{array}$ & $\begin{array}{l}\text { Pre-service } \\
\text { teachers, students }\end{array}$ \\
\hline $\begin{array}{l}\text { What could be the reasons behind air } \\
\text { pollution? }\end{array}$ & $\begin{array}{l}\text { Determining the awareness for the } \\
\text { reasons behind air pollution }\end{array}$ & $\begin{array}{l}\text { Pre-service } \\
\text { teachers, students }\end{array}$ \\
\hline $\begin{array}{l}\text { What could be the results of air } \\
\text { pollution? }\end{array}$ & $\begin{array}{l}\text { Determining the awareness for the } \\
\text { results of air pollution }\end{array}$ & $\begin{array}{l}\text { Pre-service } \\
\text { teachers, students }\end{array}$ \\
\hline $\begin{array}{l}\text { What should be done in order to } \\
\text { prevent air pollution? }\end{array}$ & $\begin{array}{l}\text { Determining the awareness for the } \\
\text { precautions against air pollution }\end{array}$ & $\begin{array}{l}\text { Pre-service } \\
\text { teachers, students }\end{array}$ \\
\hline $\begin{array}{l}\text { What do you know about the national } \\
\text { and international sanctions and their } \\
\text { contents about air pollution? }\end{array}$ & $\begin{array}{l}\text { Determining the awareness for the } \\
\text { precautions against air pollution }\end{array}$ & $\begin{array}{l}\text { Pre-service } \\
\text { teachers }\end{array}$ \\
\hline $\begin{array}{l}\text { Do you think there is air pollution in } \\
\text { Giresun? Please explain your answer } \\
\text { with the reasons. }\end{array}$ & $\begin{array}{l}\text { Determining the air pollution } \\
\text { awareness for the immediate } \\
\text { surroundings }\end{array}$ & $\begin{array}{l}\text { Pre-service } \\
\text { teachers }\end{array}$ \\
\hline $\begin{array}{l}\text { If there is air pollution in Giresun, how } \\
\text { does it affect you and your } \\
\text { surroundings? Explain. }\end{array}$ & $\begin{array}{l}\text { Determining the awareness for the } \\
\text { effects of air pollution to the } \\
\text { immediate surroundings }\end{array}$ & $\begin{array}{l}\text { Pre-service } \\
\text { teachers }\end{array}$ \\
\hline $\begin{array}{l}\text { What do you do or want to do in order } \\
\text { to prevent or decrease air pollution? }\end{array}$ & $\begin{array}{l}\text { Determining the awareness on what } \\
\text { the self can do in order to prevent air } \\
\text { pollution }\end{array}$ & $\begin{array}{l}\text { Pre-service } \\
\text { teachers }\end{array}$ \\
\hline
\end{tabular}


The answers given by the pre-service teachers have been analyzed by two separate researchers after going through code determination and theme creation stages. During the coding, in the case of researchers not agreeing under which theme the codes determined in the expressions of the students can be coded, various books on environmental issues (Güney, 2004; Özey, 2009) have been consulted and the decisions have been made accordingly. The researchers have concluded the analysis after coming to an agreement after the discussions. For the reliability -the student answers have also been analyzed separately by two researchers, after comparing them with the themes and codes created for the pre-service teachers. Since a student can answer in more than one code, the same student can be placed under different code or theme categories. The results obtained from the analysis are presented below.

The answers given by the pre-service teachers and students to the question about the description of air pollution are presented in Table 2.

Table 2.

Answers Given to the Question about the Description of Air Pollution.

\begin{tabular}{llcccc}
\hline Theme & Code & $\mathrm{PT}^{*}$ & $\mathrm{PT}(\%)$ & $\mathrm{S}^{*}$ & $\mathrm{~S}(\%)$ \\
\hline Cause & Pollution of clean air & 3 & 09.68 & 49 & 43.36 \\
& Human activities & 8 & 25.81 & 31 & 27.43 \\
& Mixing harmful gases to the atmosphere & 13 & 41.94 & 29 & 25.66 \\
& Increase in the harmful gas ratio & 6 & 19.35 & 5 & 04.42 \\
& Natural and human activities & 3 & 09.68 & 1 & 00.88 \\
& Natural activities & - & - & 1 & 00.88 \\
& Increase in the polluters & 2 & 06.45 & - & - \\
\hline Effect & Harm to living organisms & 5 & 16.13 & 5 & 04.42 \\
& Harm to the nature & - & - & 3 & 02.65 \\
& Harm to the nature and living organisms & 2 & 06.45 & 2 & 01.77 \\
& Nature not being able to renew itself & 2 & 06.45 & - & - \\
\hline
\end{tabular}

*PT: Pre-service teachers; S: Students

Air pollution is the increase of gases and particles in the atmosphere to a level where it is harmful to humans, other living organisms and property (URL - 1). In other words, air pollution is the increase of the gas and particle ratio in the atmosphere (Özey, 2009). Pre-service teachers and students have tried to explain air pollution with its causes and effects (Table 2). The answers given by the teachers indicate that the code "mixing harmful gases to the atmosphere" is the most frequent answer with a ratio of $41.94 \%$. Human activities code is also frequently encountered in the answers (25.81\%). For the students, "pollution of clean air" is the most frequently encountered code with a ratio of $43.36 \%$. The codes "human activities" (27.43\%) and "mixing harmful gases to the atmosphere" $(25.66 \%)$ are also frequently seen among the answers from students. Gases that are considered to be harmful to humans are constantly in the air. However, the increase in the amount of these gases is important for the air pollution (Özey, 2009). Hence the "mixing harmful gases to the atmosphere" code which is frequently expressed by pre-service teachers and students in their answers cannot be considered as correct answer. The code "pollution of clean air" which has been used as the answer by most of the students is more of a play on words rather than a description. In this context, since it is not possible to determine the situation which the students perceive as "pollution", it is apparent that this code cannot be considered as correct/scientific. Most students have tried to bring explanations about this code, and this can indicate that they are having difficulty in describing the air pollution. The "human activities" code which has been used frequently in the answers of both groups demonstrates that these both groups are aware that humans have an impact on creating air pollution. 
The pre-service teachers and students who tried to describe air pollution by explaining the effects of air pollution mentioned various harmful effects of air pollution. In the study conducted by Önal and Güngördü (2008) on senior students in social studies education department, most of the pre-service teachers described the polluted air as "the situation that can have negative impact on living organisms". The expressions about harmful gases also come up in the attempts at explaining air pollution by using the causes. Various descriptions of air pollution also mention the harmful effects of pollution on living organisms and the nature. In the definition that is used in this study, the term "harmful gases and particles" from the expression "increase in the ratio of harmful gases and particles in the atmosphere" is related to the criteria of air pollution being harmful to living organisms. However, both groups have tried to bring explanation through living organisms without mentioning economic, cultural and psychological impacts of air pollution, and this implies that they may not be aware of these harmful effects.

The answers given by the pre-service teachers and students to the second question about the causes of air pollution are presented in Table 3.

Table 3.

Answers to the Question about the Causes of Air Pollution.

\begin{tabular}{llcccc}
\hline Theme & Code & PT & PT(\%) & S & S(\%) \\
\hline Human causes & Industry & 28 & 90.32 & 44 & 38.94 \\
& Motors & 20 & 64.52 & 38 & 33.63 \\
& Heating & 17 & 54.84 & 33 & 29.20 \\
& Wastes & 6 & 19.35 & 21 & 18.58 \\
& Smoking & - & - & 9 & 07.96 \\
& Human activities & 3 & 09.68 & 5 & 04.42 \\
& Destruction of forests & 1 & 03.23 & 4 & 03.54 \\
& Personal care & 8 & 25.81 & 1 & 00.88 \\
& Lack of education & 1 & 03.23 & 1 & 00.88 \\
& Unplanned urbanization & 2 & 06.45 & - & - \\
& Lack of forestation & 2 & 06.45 & - & - \\
& Forest fires & 2 & 06.45 & - & - \\
& Greenhouse gases & 2 & 06.45 & - & - \\
& Fires & 1 & 03.23 & - & - \\
\hline Natural Causes & Volcanoes & 5 & 16.13 & - & - \\
& Earthquakes & 1 & 03.23 & - & - \\
\hline
\end{tabular}

While all the answers given by the pre-service teachers to the question about the causes of air pollution are distributed around human and natural causes themes, the answers given by the students are all concentrated in the human causes theme (Table 3). This indicates that the students are not aware of the fact that the air can also be polluted through natural causes. In both students and pre-service teachers, most of the human causes are expressed by the codes of industry, motors, heating and wastes. While $90.32 \%$ of the pre-service teachers mention industry in their answers, only $44 \%$ of the students mentioned industry, which may imply that the pre-service teachers consider industry as a more important factor in pollution. $64 \%$ of the pre-service teachers and $33 \%$ of the students mentioned the code associated with motors. This code is specifically associated with the exhaust gases emitted because of car motors. Similarly, the study conducted by Thornber, Stanisstreet and Boyes (1999) shows that, transportation and industry are the most important causes of air pollution according to students with ages 10 to 11 .

One may think only about pollution of outdoor air when thinking about air pollution. However, the fact that the students regarding smoking as one of the causes of air pollution, being disturbed from 
smoking in their daily lives, observing that the smokers around them prefer open air environments such as balconies can indicate that they are aware of the fact that smoking causes indoor air pollution. Güllü (2013) expressed that the particles created from burning cigarettes can cause air pollution in indoor environments. However, since the effect of smoking on the ratio of harmful gases in the atmosphere cannot be very large, it may be disregarded as the cause of air pollution.

Both pre-service teachers and the students have stated many plausible causes for air pollution. However, the causes written in their answers indicate that the most frequently stated causes are the ones that are difficult for them to intervene at their current situation. While the "personal care" code has been stated by $25 \%$ of the pre-service teachers, only $0.88 \%$ of the students mention this code in their answers. This indicates that the students are not aware of the fact that using personal care products can cause air pollution.

The answers given by the pre-service teachers and students to the question about the effects of air pollution are presented in Table 4.

Table 4.

Answers Given to the Question about the Effects of Air Pollution.

\begin{tabular}{llcccc}
\hline Theme & Code & PT & PT(\%) & S & S(\%) \\
\hline Living beings & Health & 26 & 83.87 & 58 & 51.33 \\
& Animals & 3 & 09.68 & 8 & 07.08 \\
& All living beings & 4 & 12.90 & 7 & 06.19 \\
& Lifespan & 1 & 03.23 & 6 & 05.31 \\
& Lack/absence of oxygen & - & - & 6 & 05.31 \\
& Plants & 5 & 16.13 & 5 & 04.42 \\
& Extinction & 3 & 09.68 & 1 & 00.88 \\
& Social life & 1 & 03.23 & 1 & 00.88 \\
& Human & - & - & 1 & 00.88 \\
& Genetic mutation & 1 & 03.23 & - & - \\
& Mental health & 1 & 03.23 & - & - \\
\hline Environment & Pollution of other physical environmental & 6 & 19.35 & 12 & 10.62 \\
& elements & & & & \\
& Bad odor in the surrounding air & - & - & 10 & 08.85 \\
& Visual pollution & & 6 & 05.31 \\
& Hole in the ozone layer/atmosphere & 2 & 06.45 & 6 & 03.54 \\
Ecological balance & 4 & 12.90 & 4 & 01.77 \\
Climate change & 4 & 12.90 & 2 & 00.88 \\
Global warming & 3 & 09.68 & 1 & 00.88 \\
Acid rains & 5 & 16.13 & 1 & - \\
\hline
\end{tabular}

The answers given by the pre-service teachers and students to the question about the effects of air pollution is distributed between the living beings and environment themes (Table 4). The code for health is the most frequently encountered code in the answers (83.87\%). This code is followed by pollution of other physical environmental elements (land, water etc.) which is under the environment theme. In the study conducted by Thornber, Stanisstreet and Boyes (1999), students (ages 10-11) have stated that plants and animals die because of air pollution and health problems, especially asthma, arise due to air pollution. According to the 2012 World Health Organization (WHO) data, millions of people have been reported to be dead due to factors related to air pollution (URL-2). In this study, it has been observed that both groups mostly mention of upper respiratory system infections under the "health" code. 
Both groups mentioned very little of the codes "extinction", "genetic mutation", "mental health", "ecological balance" and "climate change" which are under living beings and environment themes. This situation can indicate the low level of awareness for the long term effects of air pollution for both groups.

Similarly, pre-service social studies teachers stated in another study that deterioration of the texture of outdoor historical artifacts, increase in stress and nervous system disorders in humans, increase in respiratory system infections and damage to the hood of transportation vehicles are among the effects of air pollution (Önal \& Güngördü, 2008). In the study by Thornber, Stanisstreet and Boyes (1999), most of the 10-11 years old students expressed that buildings are also affected negatively by air pollution. However, in this study, neither pre-service teachers nor the students mention economic and cultural impacts of air pollution. Only one pre-service teacher stated that the air pollution can have effect on the human psychology.

The $8.85 \%$ of students have stated that the bad smell in the air or from the environment is a result of air pollution. This expression brings out the possibility that some of the students have the idea that polluted air has bad smell. However, polluted air does not necessarily smell bad. For example, gases such as nitrogen oxides $\left(\mathrm{NO}_{\mathrm{x}}\right)$ and carbon monoxide $(\mathrm{CO})$ pollute the air but they are odorless (URL-3). Similarly, $6.45 \%$ of the pre-service teachers and $5.3 \%$ of the students stated that the air pollution causes visual pollution. In contrast to these answers from the pre-service teachers and students, the color of air does not have to be different when polluted. For example, gases which cause air pollution such as nitrogen oxides $\left(\mathrm{NO}_{\mathrm{x}}\right)$, sulphur dioxide $\left(\mathrm{SO}_{2}\right)$, carbon monoxide (CO) are also colorless (URL-3). In the study by Sadık, Çakan and Artut (2009), when the students aged 11-12 are asked to make drawings about air pollution, it has been observed that they painted the sky in black or grey. This finding is worth noting since it implies that there is a possibility of pre-service teachers and students having the idea that there is air pollution in places where there are bad smelling and different colored air layers. Darçın and Sert-Çıbık (2009) and Boyes, Stanisstreet and Yeung (2004) also stated that the pre-service science teachers have alternative concepts such as the polluted air has bad smell or color.

The answers given by the pre-service teachers and students to the question about what can be done in order to prevent air pollution are presented in Table 5.

Table 5.

Answers Given to the Question about What Can Be Done in Order to Prevent Air Pollution.

\begin{tabular}{llcccc}
\hline Theme & Code & PT & PT(\%) & S & S(\%) \\
\hline Industrial/ & Filters & 20 & 64.52 & 57 & 50.44 \\
Household & Treatment facility & - & - & 2 & 01.77 \\
& Chimney cleaning & - & - & 1 & 00.88 \\
\hline \multirow{2}{*}{ Education } & Awareness raising & 17 & 54.84 & 15 & 13.27 \\
& Warning the polluters & - & - & 4 & 03.54 \\
& Formal education & 2 & 06.45 & - & - \\
\hline Agricultural & Forestation/not cutting the trees down & 7 & 22.58 & 13 & 11.50 \\
activities & Reducing pesticides & 1 & 03.23 & - & - \\
\hline Heating & Reducing fossil fuel consumption & 7 & 22.58 & 2 & 01.77 \\
& Heat insulation & 1 & 03.23 & 1 & 00.88 \\
& Quality coal consumption & 5 & 16.13 & 1 & 00.88 \\
& Natural gas consumption & 2 & 06.45 & 1 & 00.88 \\
& Responsible fuel consumption & - & - & 1 & 00.88 \\
\hline Government & Inspection & 1 & 03.23 & - & - \\
policies & Urban planning & 3 & 09.68 & - & - \\
& Status assessment, planning & 2 & 06.45 & - & - \\
\hline Other & Public transportation & 9 & 29.03 & 4 & 03.54 \\
\hline 94 & & & & &
\end{tabular}


Funda AYDIN GÜÇ et al.- Çukurova Üniversitesi Eğitim Fakültesi Dergisi, 46(1), 2017, 85-133

Reducing gas emission
Banning smoking
Ventilating house/indoors
Protecting the nature
Personal care
Preventing forest fires
Creating inventions
Recycling

\begin{tabular}{cccc}
- & - & 4 & 03.54 \\
- & - & 3 & 02.65 \\
- & - & 2 & 01.77 \\
- & - & 2 & 01.77 \\
6 & 19.35 & 1 & 00.88 \\
- & - & 1 & 00.88 \\
- & - & 1 & 00.88 \\
2 & 06.45 & - & - \\
\hline
\end{tabular}

Majority of the pre-service teachers and the students have answered the question about what can be done in order to prevent air pollution within the theme of industry/household (Table 5). $64.52 \%$ of the pre-service teachers and $50.44 \%$ of the students mentioned the necessity of using filters. These filters are the ones that should be used in the factory chimneys and regular house chimneys. Similarly, industry is the most frequently encountered code in the question about the causes of air pollution as well.

While both pre-service teachers and students hardly mention the lack of education about the causes of air pollution (Table 3), when asked about what should be done in order to prevent air pollution, $54.84 \%$ of the pre-service teachers and $13.27 \%$ of the students gave answers with the raising awareness code which is under the education theme. The "raising awareness" code includes activities such as campaigns, slogans, public service announcements, seminars and questionnaire implementations. In the code about education and awareness rising, the pre-service teachers express more various reasons in their answers; this can be associated with the fact that their awareness is at a higher level due to the classes they have taken about environment and environmental issues during their undergraduate education.

While $25 \%$ of the pre-service teachers mention the personal care products as one of the causes for air pollution, only $19.35 \%$ of them state the necessity of reducing the consumption of such products in order to prevent air pollution. In the causes and precautions questions, only one student mentions the personal care products. While being an individual activity, reducing the usage of personal care products also means that the individuals can reduce the damage they give to the environment by themselves, without resorting to additional activities. Hence it can be said that the level of awareness for this issue is low in the students.

No student stated the need for development of government policies in order to prevent air pollution, which can be explained by the fact that they are at a young age. On the other hand, the fact that only $19.36 \%$ pre-service teachers giving the answer in this theme, indicates that the level of awareness is low about the subject of precautions that need to be taken by the government for environmental issues which can affect the future generations such as air pollution. Due to their levels of development, the students are not expected to have knowledge on the government policies, and national and international sanctions. Hence, the questions in this scope are only asked to pre-service teachers.

The answers given by the pre-service teachers to the question about the national and international sanctions related to air pollution are presented in Table 6.

Table 6.

Answers Given by the Pre-Service Teachers to the Question about the National and International Sanctions Related to Air Pollution.

\begin{tabular}{llcc}
\hline Theme & Code & PT & PT(\%) \\
\hline KYOTO Protocol & Precautions on the gases emitted to the atmosphere & 2 & 06.45 \\
& - & 1 & 03.23 \\
\hline
\end{tabular}


Funda AYDIN GÜç et al.- Çukurova Üniversitesi Eğitim Fakültesi Dergisi, 46(1), 2017, 85-133

\begin{tabular}{llll}
\hline TEMA & Forestation & 1 & 03.23 \\
& Environmental activities & 1 & 03.23 \\
& - & 1 & 03.23 \\
\hline Other & Penal sanctions & 1 & 03.23 \\
& Forestation & 1 & 03.23 \\
& Warning and embargo & 1 & 03.23 \\
& Greenpeace & 1 & 03.23 \\
& Air pollution measurement stations & 1 & 03.23 \\
& Smoke-free air space & 1 & 03.23 \\
\hline
\end{tabular}

It can be seen that very few number of pre-service teachers have answered this question about the national and international sanctions aimed at preventing air pollution (Table 6). It can also be observed that the pre-service teachers answering this question mention activities of foundations such as The Turkish Foundation for Combating Soil Erosion, for Reforestation and the Protection of Natural Habitats (TEMA), in addition to various other campaigns. The only example among the answers that can be considered as a sanction is the KYOTO Protocol. Other studies conducted with university students comply with this result (Karatekin, Kuş \& Merey, 2014; Oğuz, Çakçı \& Kavas, 2011).

The answers given by the pre-service teachers to the question on whether there is air pollution in Giresun (the city you reside in) are presented in Table 7.

Table 7.

Answers Given by the Pre-Service Teachers to the Question on Whether There Is Air Pollution in Giresun.

\begin{tabular}{llcc}
\hline Decision & Code & PT & PT(\%) \\
\hline Yes & Coal consumption & 20 & 64.52 \\
& Geographical structure/settlement & 7 & 22.58 \\
& Smog & 7 & 22.58 \\
& Respiratory distress & 6 & 19.35 \\
& Unfiltered chimney & 3 & 09.68 \\
& Low quality fuel consumption & 3 & 09.68 \\
& Harmful wastes disposed in the sea & 1 & 03.23 \\
& Forest destruction & 1 & 03.23 \\
\hline Partially yes & Woodland area & 1 & 03.23 \\
\hline No answer & Unfiltered chimney & 1 & 03.23 \\
& Car exhaust & 1 & 03.23 \\
\hline
\end{tabular}

Almost all the pre-service teachers have stated that there is air pollution in Giresun and they identified the main the causes as more coal consumption (64.52\%) and respiratory distress (19.35\%). The major reason behind this answer can be the fact that this study has been conducted during the winter and hence there is an increase in coal usage in the city for heating. Giresun City Environmental Status Report (2012) states that there is an increase in the air pollution in the area during winter months due to increase in coal consumption.

The $22.58 \%$ of pre-service teachers express that there is air pollution due to geographical structure and settlement while $22.58 \%$ mention smog. Giresun is a coastal city on the skirts of Giresun mountain range. The reason behind these explanations can be the fact that the smoke emitted from heating systems during the winter not being able to spread around due to mountains and the smog being settled on the city due to lack of winds because of the coast type. In another study conducted in Samsun which is close to Giresun and has similar geographical characteristics, the participants state that the air pollution can be felt during winter days, and especially during morning hours, when the polluted air is spread to the city (Şahin 2004). The fact that the air pollution in Giresun, which is the city this study has 96 
been conducted in, is seasonal has also been stated in the reports (Giresun City Environmental Status Report, 2012). However it can be seen that none of the pre-service teachers make note of this seasonal air pollution.

The answers given by the pre-service teachers to the question on the effects of possible air pollution in Giresun are presented in Table 8.

Table 8.

The Answers Given by the Pre-Service Teachers to the Question on the Effects of Possible Air Pollution in Giresun.

\begin{tabular}{llcl}
\hline Theme & Code & PT & PT(\%) \\
\hline Living beings & Health & 25 & 80.65 \\
& Social life & 3 & 09.68 \\
& Mental health & 1 & 03.23 \\
& Genetic mutation & 1 & 03.23 \\
\hline Environment & Climate change & 1 & 03.23 \\
& Visual pollution & 1 & 03.23 \\
\hline Other & Smell & 3 & 09.68 \\
& Laundry & 1 & 03.23 \\
\hline
\end{tabular}

While the pre-service teachers explain effects of the possible air pollution in Giresun under the theme of living beings, they mainly (80.65\%) mention the "health" code under this theme (Table 8). The answers under the health code reveal that they mostly mention the problems they have about respiratory system. In various studies, individuals mainly have the opinion that the air pollution causes health problems, especially upper respiratory system problems (Oğuz, Çakçı \& Kavas, 2011; Şahin, 2004; Önal \& Güngördü, 2008).

Similar to the previous questions, the pre-service teachers have not mentioned the economic and cultural effects of air pollution in this question. There are more diverse codes in the answers to the question about the effects of air pollution than this question (Table 4), and this indicates that the preservice teachers think that not all the results of air pollution directly affect them or their environment.

The answers given by the pre-service teachers to the question about what they can do in order to prevent or reduce air pollution are presented in Table 9.

Table 9.

The Answers Given by the Pre-Service Teachers to the Question about What They Can Do in Order to Prevent or Reduce Air Pollution.

\begin{tabular}{llcl}
\hline Theme & Code & PT & PT(\%) \\
\hline Education & Raising awareness & 14 & 45.16 \\
& Learning & 2 & 06.45 \\
\hline Heating & Quality fuel consumption & 2 & 06.45 \\
& Natural gas consumption & 2 & 06.45 \\
& Reducing fossil fuel consumption & 1 & 03.23 \\
\hline Agricultural activities & Forestation & 3 & 09.68 \\
\hline Industry/household & Filters & 1 & 03.23 \\
\hline Government policies & Inspection & 1 & 03.23 \\
\hline Other & Public transportation & 6 & 19.35 \\
& Personal care products & 5 & 16.13 \\
& Smoking & 1 & 03.23 \\
\hline
\end{tabular}


The teachers have explained the actions they can take in order to prevent air pollution mainly (54.16\%) with the raising awareness code under the education theme (Table 9). In the question about what can be done in order to prevent air pollution, they mentioned this code with a $54.84 \%$ ratio (Table $5)$, and this indicates that the people who think that awareness raising is necessary for this issue do not intend to do the activities to raise their own awareness at the same time. The reason behind this can be not knowing how to do this or really not being interested in doing it. The fact that there more diverse codes in the answers to the questions about how to prevent the air pollution than this question also indicate that the pre-service teachers limit themselves on what they can do in order to prevent air pollution. This limitation also reveals itself especially in the government policies and industry/household themes and public transportation usage code under the other theme.

When the results of the needs analysis are interpreted, the general picture shows that when the preservice teachers and students try to define air pollution, they marginally mention or do not mention at all the issues and concepts such as atmosphere, carbon monoxide, carbon dioxide, fossil fuels, sulphur dioxide, acid rains, global warming, damage to the ozone layer, chlorofluorocarbon. Moreover, there are very few number of pre-service teachers and students who can express that air pollution is the increase of the ratio of harmful gases in the atmosphere. In addition, there are no pre-service teachers or students who mention particles in the air when defining air pollution. This fact shows that neither preservice teachers nor the students have sufficient knowledge on essential concepts to describe the air pollution.

Both the pre-service teachers and the students generally attribute the causes of air pollution to human activities. This indicates that the idea of natural causes such as geographical structure of the settlements or natural disasters being among the causes of air pollution has not yet formed. While the pre-teachers see the usage of personal care products as one of the causes of pollution, very few students have mentioned this subject, which indicates that the students have not yet developed the awareness on the issue that individuals can pollute the air by themselves. The fact that smoking issue is addressed by the students but not by the pre-service teachers, and the fact that gases emitted by burning cigarettes are described as air polluter by the students but not by the pre-service teachers can indicate that they do not regard smoking as a factor in causing air pollution. On the issue of effects of air pollution, almost no participants in both groups mention the economic costs due to damage of pollution to factors such as materials, surroundings or health, and cultural impact of the air pollution such as corrosive effect on statues, historical artifacts. The effect of air pollution most frequently mentioned is the health of humans and other living organisms. This outcome indicates that in both groups, the level of awareness on the results of air pollution and its impact on the society is low.

On the subject of preventing air pollution, both groups mainly mention about the precautions that they can have difficulties in applying themselves. Precautions that reduce the individual contribution such as reducing the usage of personal care products or using public transportation have been mentioned very marginally by both groups.

The fact that codes such as extinction, genetic mutation, ecological balance and climate change have been addressed very little by both groups can be the indication of low levels of awareness in both groups about many issues that can become important in the future for both living organisms and the environment. Additionally, it has also been observed that the pre-service teachers have almost no knowledge on the national and international sanctions about air pollution.

In the light of all these findings, it is apparent that neither the pre-service teachers nor the students have sufficient knowledge and awareness on the basic concepts about air pollution, causes, effects and future implications of pollution, and the national and international sanctions about the issue; and there is a need for remedy these shortcomings and increasing awareness on these issues.

The results of the needs analysis have been discussed by the researchers, common points that are lacking about the awareness on air pollution in pre-service teachers and students have been determined 
and these common points are defined as "focus points". The focus points that need to be emphasized in order to create and increase the awareness on air pollution are presented in Figure 2.

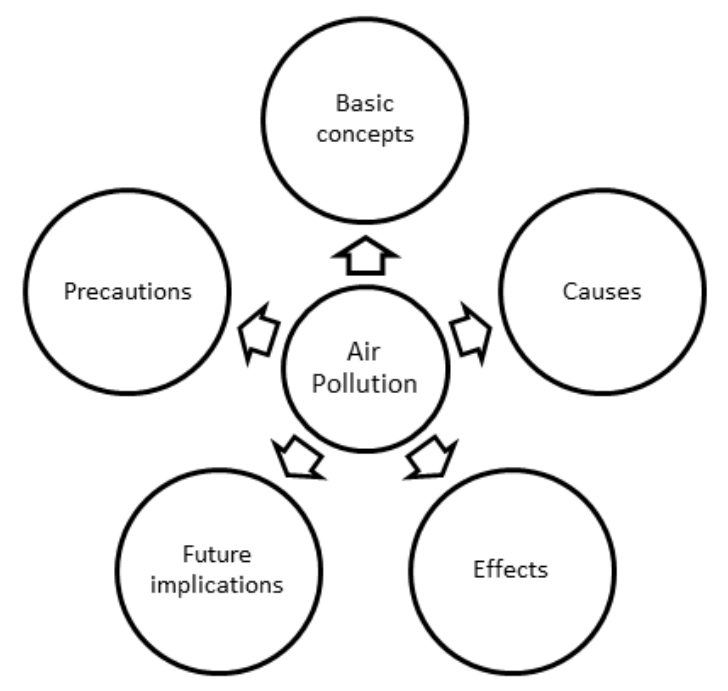

Figure 2. Focus points that resulted from needs analysis

The contents of the focus points determined by the researchers and the primary school fourth grade educational programs of different disciplines have been discussed and a specific discipline has been appointed for each focus point. Then, the order of the focus points have been discussed and the decision been made about which focus point should be given in which order. The focus points, their contents and the associated disciplines with respect to their orders are presented in Table 10.

Table 10.

Focus Points, Contents and Related Disciplines.

\begin{tabular}{lll}
\hline Focus Point & Content & Discipline \\
\hline Basic concepts & Basic concepts related to air pollution & Turkish \\
Causes & Natural and human causes of air pollution & Social Studies \\
Effects & $\begin{array}{l}\text { The effects of air pollution within the context of living beings } \\
\text { and environment, impact of air pollution on the society }\end{array}$ & Science \\
Future & $\begin{array}{l}\text { Predicting the future situation according to the past and } \\
\text { present air pollution and according to the existing conditions }\end{array}$ & Mathematics \\
implications & $\begin{array}{l}\text { Regulations, conventions, sanctions, opinions of public } \\
\text { Precautions }\end{array}$ & Public \\
& precautions & Administration \\
\hline
\end{tabular}

As seen in Table 10, it is decided that it is more suitable to start working first on the basic concepts about air pollution. For this purpose, the concepts of atmosphere, carbon monoxide, carbon dioxide, fossil fuels, sulphur dioxide, acid rains, and global warming are determined and Turkish discipline has been chosen in order to teach these concepts. Learning the basic concepts about air pollution is essential to set up a basis for other focus points. After the basic concepts, it is thought that the awareness towards the causes of air pollution should be created. Since this focus point consists of natural and human factors causing air pollution, it has been associated with social studies. The focus point on the effects of air pollution has been associated with the discipline of science in order to discuss 
the effects of air pollution on human health, results of air pollution, and the impact of these results on the society within the context of living beings and the environment. Taking the status of air pollution from past to present into consideration, predicting the future status is highly essential in taking the necessary precautions for the future. In this respect, it has been deemed appropriate that there should be awareness raising activities carried out for the prediction of future situation after the air pollution causes and effects focus points. Since this focus point contains predictions of future based on the data from the past, it has been associated with the discipline of mathematics. Lastly, in order to raise awareness on the measures that are/can be taken in order to prevent air pollution, the focus points on precautions, which contains the regulations, conventions and sanctions has been associated with the discipline of public administration. The development process of the designed contents is presented in the next chapter in detail.

\section{Project Development}

Development stage of the project is explained under two sub-sections: pilot study and changes made after pilot study.

\section{Pilot Study}

Project development process is composed of four stages: implementation of pre-tests and CSPC, community service, and implementation of post-tests.

\section{Implementation of Pre-Tests}

In the implementation of pre-tests stage, firstly APAQ-II is applied to pre-service teachers and students. These pre-service teachers and students are the same as to participate in the need analysis. APAQ-II is the questionnaire created by the researchers after extending the contents of APAQ which was prepared for the needs analysis. A need for extending the contents of APAQ used in the needs analysis have arisen because the analysis shows that pre-service teachers or the students do not mention some issues on air pollution at all. For example, it has become apparent that neither pre-service teachers nor the students have used expressions in their answers to the questionnaire, towards future problems that can arise due to air pollution, and that they have made assessments according to the present situation. Considering the past and the present situation is highly essential in making predictions for the future and taking the necessary precautions. In this respect, the necessity of raising awareness for this purpose arises. Hence the question "What future problems can we encounter if the precautions about air pollutions are not taken?" is added to APAQ. The questions in APAQ-II and their purposes are presented in Table 11.

Table 11.

Questions Added to APAQ-II, Their Purposes, and Groups whom are Asked the Questions.

\begin{tabular}{|c|c|c|}
\hline Question & Purpose & Group \\
\hline How do you define air? Elaborate. & $\begin{array}{l}\text { Determining the general point } \\
\text { of view on basic concepts }\end{array}$ & $\begin{array}{l}\text { Pre-service } \\
\text { teachers, students }\end{array}$ \\
\hline How do you define pollution? Elaborate. & $\begin{array}{l}\text { Determining the general point } \\
\text { of view on basic concepts }\end{array}$ & $\begin{array}{l}\text { Pre-service } \\
\text { teachers, students }\end{array}$ \\
\hline $\begin{array}{l}\text { What kinds of regional or national activities } \\
\text { do you encounter in your daily life about air } \\
\text { pollution? Explain with examples. }\end{array}$ & $\begin{array}{l}\text { Determining the awareness } \\
\text { about precautions against air } \\
\text { pollution }\end{array}$ & $\begin{array}{l}\text { Pre-service } \\
\text { teachers, students }\end{array}$ \\
\hline $\begin{array}{l}\text { What future problems can we encounter if } \\
\text { the precautions about air pollutions are not } \\
\text { taken? }\end{array}$ & $\begin{array}{l}\text { Determining the awareness } \\
\text { about the effects of air } \\
\text { pollution }\end{array}$ & $\begin{array}{l}\text { Pre-service } \\
\text { teachers, students }\end{array}$ \\
\hline
\end{tabular}


During the implementation of pre-tests stage, additional questions "What do I know?" and "What do I want to know?" from the Know-Want-Learn (KWL) form have also been asked; which are expected to provide an opportunity of self-assessment for pre-service teachers for what they know, what they want to know and what they gain at the end of CSPC regarding air pollution. With the KWL form, it is aimed to present the pre-service teachers' current and incomplete information about air pollution and their selfevaluations for the acquisitions they get within the scope of the project.

\section{Implementation of CSPC}

The implementation plan -for the courses offered in the department which have been designed within the scope of the project- of CSPC which takes 14 weeks in total is presented in Table 12.

Table 12.

Implementation Plan for the Courses in the Department within the Scope of CSPC.

\begin{tabular}{cl}
\hline Week & Implementation \\
\hline 1 & Pre-tests and pre-research \\
\hline 2 & $\begin{array}{l}\text { Pre-service teachers being divided into groups, determining focus points } \\
\text { (disciplines) for each group, studying the relation between the focus points } \\
\text { and disciplines }\end{array}$ \\
\hline $3-4$ & $\begin{array}{l}\text { Groups preparing course plans suitable for their focus points under the } \\
\text { guidance of their advisors }\end{array}$ \\
\hline 5-6-7-8-9-10-11-12 & Seminar preparations and seminars \\
\hline $13-14$ & Evaluation presentation of the groups and post-tests \\
\hline
\end{tabular}

The content presented in Table 12 is explained in detail below:

- $\quad$ Pre-tests (APAQ-II and KWL form) have been applied to the pre-service teachers in the department.

- The pre-service teachers conducted preliminary research about what air pollution is, its causes, effects, and national and international studies about air pollution.

- $\quad$ Focus points (disciplines) for each five voluntary groups have been determined by lot.

- Seminar preparation stage for community service has started. The preparations for seminars have started. During this stage, the purpose and scope of the focus points have been introduced by the advisors (experts on related disciplines).

- $\quad$ The advisors have asked the pre-service teachers to investigate the relation between the focus points of their groups and related disciplines.

- Group members and advisors have kept studying regularly each week by gathering outside CSPC hours.

- At the end of their investigations, the pre-service teachers have determined the gains in their disciplines that can be associated to their focus points, and developed interdisciplinary course plans. During this stage, special attention has been given to activities which are suitable for interdisciplinary learning/teaching environments and that will produce new knowledge with the help of subsequent seminars and will enable new connections between disciplines, for the disciplines selected in accordance with air pollution and associated focus points.

- Advisors have provided guidance to the pre-service teachers during the stage of course plan development.

- In the seminar preparation classes, every week during CSPC hours, all advisors and pre-service teachers have evaluated the group studies within the context of focus points, scope, gains towards the discipline, and interdisciplinary approach; and the pre-service teachers have been given the 
necessary feedbacks. These classes have provided the opportunity for all the groups working on different disciplines to work together, contribute to the works of each other, and making connections between disciplines; and these activities in turn have established the interdisciplinary nature of the learning-teaching activities carried out within the scope of CSPC.

- Pre-service teachers have finalized their course plans on their disciplines by making the necessary adjustments in light of the feedbacks from other advisors and groups.

- The course plans completed according to the focus point order have been applied in the primary schools as seminars for the purpose of community service. While the course plans for one focus point was being applied in a school, the preparations for the following other focus points have continued.

- At the end of community service stage, the pre-teachers shared their experiences, about these implementations in the primary schools with discipline experts and pre-service teachers in other groups; and the aspects that are lacking or good in the implementations are tried to be determined through class discussions.

- After all the groups have completed their seminar work, the final stage of the project, post-test implementation has been conducted in order to determine whether the project contributed to the awareness about air pollution. APAQ-II and the last question of KWL form have been applied as the post-test to the pre-service teachers.

\section{Community Service}

Community service stage of CPSC has been carried out by the pre-service teachers giving seminars in selected schools. These schools and students are identical to the schools identified in the need analysis. Although they are called seminars since this process has been planned and implemented independent from the course plans of the students in, these activities are carried out with active participation from the students. These activities include various methods such as drama, experiment, brainstorming and observation, which are in accordance with the course plans prepared by adopting the constructivist approach. While the seminars were being held, the pre-service teachers were not guided either by the teachers of the class or by their advisors. Guidance was given during the preparation period of the seminars and after each seminar by the group advisors.

The pre-service teachers can spend two hours each week to these seminars in accordance with their course schedules. Hence, each group completed the seminars in a total of four weeks with a different school each week. The weekly schedule of the seminars conducted in the primary schools is presented in Table 13.

Table 13.

Seminar Implementation Plan within the Context of Community Service.

\begin{tabular}{ccccc}
\hline \multirow{2}{*}{ Week } & \multicolumn{4}{c}{ Primary School } \\
\cline { 2 - 4 } & A & B & C & D \\
\hline $1-2-3$ & No implementation has been made due to ongoing seminar preparations. \\
\hline 4 & Pre-test & & & \\
\hline 5 & Turkish & Pre-test & & \\
\hline 6 & Social Studies & Turkish & Pre-test & Pre-test \\
\hline 7 & Science & Social Studies & Turkish & Turkish \\
\hline 8 & Mathematics & Science & Social Studies & Social Studies \\
\hline 9 & PublicAdministration & Mathematics & Science & Science \\
\hline 10 & Post-test & PublicAdministration & Mathematics & Mathematics \\
\hline 11 & & Post-test & PublicAdministration &
\end{tabular}


Funda AYDIN GÜÇ et al.- Çukurova Üniversitesi Eğitim Fakültesi Dergisi, 46(1), 2017, 85-133

\begin{tabular}{ccc}
\hline 12 & Post-test & PublicAdministration \\
\hline 13 & & \\
\hline 14 & No implementation has been done. & \\
\hline
\end{tabular}

As seen in Table 13, seminars have been conducted in four different primary schools. Two classes randomly selected from each school have gathered in the seminar rooms and attended the seminars that last for two hours for five weeks. With the addition of one week of pre-tests and one week of posttests (APAQ-II), the implementation has lasted for seven weeks in total.

The seminars have been conducted with the order of Turkish, Social Studies, Science, Mathematics and Public Administration disciplines in relation with the focus points. Hence, while the pre-service teachers are working with the students in the field of their disciplines, they transfer the concepts of focus points of their group to their students at the same time. The students have attended the seminars within the context of focus points under predetermined themes, without being informed about the differences in the disciplines. Therefore, during this community service stage, both pre-service teachers and the students acquired interdisciplinary knowledge and awareness on a socio-scientific subject, and in addition, the pre-service teachers have gained teaching experience.

\section{Changes Made After the Pilot Study}

Based on the results of the pilot study conducted within the scope of project development, data gathering instruments and the focus/content/order relation of the course plans created by the preservice teachers have been evaluated.

\section{Changes Made to the Data Gathering Instruments}

Content analysis on the obtained data from APAQ-II has been used in order to determine whether the questions in the data gathering instruments fit their purposes. As a result, it has been confirmed that APAQ-II is a suitable data gathering instrument for determining the awareness of pre-service teachers and students. Even so, some of the questions needed to be changed and some questions had to be removed from the questionnaire. For example, it has been decided that the question "What do you encounter about air pollution in mass communication devices such as television, internet, magazines, newspapers and radio?" need to be changed. The students have responded to this question by mentioning their communication with the group, because they did not know the meaning of the term "mass communication devices". Hence proper data compatible with the purpose of the question could not be obtained. Instead of the term "mass communication devices", the question has been changed using the expression "Communication devices such as television, newspapers, internet..." in order to make it more understandable by the students. The purpose of the question "What kind of problems can we encounter in the future if no precautions are taken against air pollution?" is to determine the awareness created within the concept of focus point of future status under the discipline of mathematics. However, the analysis of the answers given by the pre-service teachers and the students indicate that the emerging codes for this question are the same with the codes seen in the answers for the question "What are the effects of air pollution?". Therefore this question has been decided to be removed from the questionnaire. After the changes made according to the results obtained from the pilot study, APAQ-III has been created. The questions in APAQ-III are presented in Table 14. 
Table 14.

Questions in APAQ-III, and Groups whom are Asked the Questions.

\begin{tabular}{|c|c|c|}
\hline Question & Purpose & Group \\
\hline How do you define air pollution? Explain. & $\begin{array}{l}\text { Determining the general point of } \\
\text { view on air pollution awareness }\end{array}$ & $\begin{array}{l}\text { Pre-service } \\
\text { teachers, students }\end{array}$ \\
\hline $\begin{array}{l}\text { What can be the reasons for air pollution? } \\
\text { Explain. }\end{array}$ & $\begin{array}{l}\text { Determining the awareness on the } \\
\text { causes of air pollution }\end{array}$ & $\begin{array}{l}\text { Pre-service } \\
\text { teachers, students }\end{array}$ \\
\hline $\begin{array}{l}\text { What can be the results of air pollution? } \\
\text { Explain. }\end{array}$ & $\begin{array}{l}\text { Determining the awareness on the } \\
\text { effects of air pollution }\end{array}$ & $\begin{array}{l}\text { Pre-service } \\
\text { teachers, students }\end{array}$ \\
\hline $\begin{array}{l}\text { What needs to be done in order to prevent } \\
\text { air pollution? }\end{array}$ & $\begin{array}{l}\text { Determining the awareness on the } \\
\text { precautions against air pollution }\end{array}$ & $\begin{array}{l}\text { Pre-service } \\
\text { teachers, students }\end{array}$ \\
\hline $\begin{array}{l}\text { Do you think there is air pollution in } \\
\text { Giresun? Please explain your answer with } \\
\text { the reasons. }\end{array}$ & $\begin{array}{l}\text { Determining the awareness on air } \\
\text { pollution in the near surroundings }\end{array}$ & $\begin{array}{l}\text { Pre-service } \\
\text { teachers, students }\end{array}$ \\
\hline $\begin{array}{l}\text { What kinds of regional or national } \\
\text { activities do you encounter in daily life } \\
\text { about air pollution? Explain with examples. }\end{array}$ & $\begin{array}{l}\text { Determining the awareness on } \\
\text { precautions against air pollution }\end{array}$ & $\begin{array}{l}\text { Pre-service } \\
\text { teachers, students }\end{array}$ \\
\hline
\end{tabular}

In Table 14, it is seen that the same questions are asked in both groups in the main implementation of the project. This is a result of the development of the questionnaire in the process. Researchers have explained how consistency is ensured both in the data collection process and in the process of analysis and interpretation of data (Yıldırım \& Şimşek, 2006). For this study the explanations of how consistency in the study is provided are presented clearly for the readers.

The content analysis performed on the data obtained with the KWL forms at the end of the pilot study indicates that the form has achieved its purpose in determining the awareness of pre-service teachers about air pollution. The KWL forms revealed that while the pre-service teachers make selfassessment on their awareness about air pollution, they also make comments about the impact of CSPC with interdisciplinary approach on their teaching experiences. In this respect, it has been decided to hold interviews with volunteer pre-service teachers from each group in the main study, in order to determine the possible implications of this project which is conducted under the scope of CSPC on the in-class and outside-class activities that the pre-service teachers can carry out during their future profession in teaching.

While preparing the interview form, it has also been aimed to actualize the goal of pre-service teachers helping the community within the scope of CSPC which is conducted with an interdisciplinary approach, as well as to obtain their opinions about the whole process. The interviews are designed as semi-structured face-to-face meetings, and the pre-service teachers have been asked ten questions. These questions are listed below:

1. Do you know the purpose of this study you participated in? If yes, what do you think it is? If not what do you think it can be? What is the purpose of your group? Do you know the purposes of other groups?

2. Do you think this study achieved its purpose (in terms of whole class and in terms of groups)? Why do you think so?

3. Do you think you help the community with this study? How?

4. Taking the implementation process of this study into consideration, what are your opinions on the whole process? Can you explain the negative and positive aspects (in terms of whole class and in terms of groups)? 
5. Can this study be classified as an interdisciplinary study? Why?

6. Did the activities carried out by other groups contribute to your knowledge on the issue? Can you elaborate on this contribution in terms of groups?

7. Did this study contribute to you in terms of teaching experience? How?

8. When you become a teacher, would you consider conducting an interdisciplinary activity in your class? Why?

9. From the perspective of a teacher, do you think there are differences between the teaching you do in primary schools and the teaching the faculty of your department does? How?

10. From the perspective of a student, are there are differences between your student experience and the student experience of the children in primary school? How?

Changes in the Focus Points, Content and Order

The order of the disciplines, focus points, contents and the changes made for the seminars to be conducted for the main study based on the class discussions about the seminars conducted within the scope of community service during the pilot study, and the knowledge acquired by the pre-service teachers about their experienced during the seminar preparation and seminars are presented in Table 15.

Table 15.

Relations of Focus Points, Contents and Disciplines in the Main Study.

\begin{tabular}{|c|c|c|c|}
\hline O.I. & Discipline & Focus Point & Content \\
\hline 1 & Turkish & Basic concepts & Basic concepts about air pollution \\
\hline 2 & Science & $\begin{array}{l}\text { Causes and } \\
\text { effects }\end{array}$ & $\begin{array}{l}\text { The effects of air pollution to the human health and } \\
\text { their social impact within the context of science } \\
\text { discipline }\end{array}$ \\
\hline 3 & Social Studies & $\begin{array}{l}\text { Causes and } \\
\text { effects }\end{array}$ & Natural and human causes and effects of air pollution \\
\hline 4 & Mathematics & Future status & $\begin{array}{l}\text { The status of air pollution in the past and the present, } \\
\text { and prediction of future status based on today's } \\
\text { conditions }\end{array}$ \\
\hline 5 & $\begin{array}{l}\text { Public } \\
\text { Administration }\end{array}$ & Precautions & $\begin{array}{l}\text { Clearing/summarizing the presentations of previous } \\
\text { groups, laws and regulations, implementations in } \\
\text { different countries, public opinion }\end{array}$ \\
\hline
\end{tabular}

O.I.: Order of Implementation

Unlike the focus points in the pilot study, it has been decided to merge two separate causes and effects focus points under one causes and effects focus point (Table 15). Since the human and natural causes of air pollution cannot be given separately from the effects, it has been decided that the social studies and science handle the causes and effects of air pollution within the context of their own disciplines. Moreover, while the science group deals with the human causes and effects of air pollution, social studies deal with the human and natural causes of air pollution together with its effects.

Pre-service teachers in the public administration group have made use of the interviews carried out with the public officials in their course plans in the pilot study. However, because they have encountered various problems during this process, the pre-service teachers in the main study have resorted to the opinions of citizens rather than public officials. Again, unlike the pilot study, the implementations about air pollution in different countries are also included in the course plans.

In addition to these, the pre-service teachers have been asked to match the gains stated in the primary school 4 th grade education program to the course plans they prepare in order for the relations 
between disciplines and focus points to be understood clearly in the main study. It is also decided that the course plans are prepared according to $5 \mathrm{E}$ teaching/learning model which is known to the preservice teachers.

\section{Main Study}

The main study of the project has been carried out in accordance with the pilot study presented in Figure 1, following the order of implementation of pre-tests, CSPC implementation, community service and implementation of post-tests stages. In the first stage, APAQ-III and KWL form are applied to preservice teachers as pre-tests. The group in which these pre-service teachers are located was randomly selected from the four groups attending CSPC classes at an education faculty for the main implementation. On the other hand, students are educated in three schools selected randomly from primary schools in the same city so that pre-service teachers can reach the CSPC course implementation process. The 32 pre-service primary school teachers and 122 fourth grade primary school students participated in the main implementation.

In the second stage, CSPC is implemented as in the pilot study (Table 12). The groups have worked together with their advisors in order to prepare the suitable course plans in accordance with the focus points, disciplines and contents presented in Table 15. The discipline-gain relations in the main study are presented in Table 16.

Table 16.

Disciplines and Gains in the Main Study.

\begin{tabular}{ll}
\hline Discipline & Gains in the curriculum \\
\hline Turkish & Making deductions from what they listen to. \\
& Making comparisons based on what they listen to. \\
& Researching the meaning of words they do not know. \\
& Sharing the things they listen with others. \\
& Developing vocabulary by making use of visuals. \\
& Guessing the meanings of the words they do not know from what they listen to. \\
& (Ministry of National Education (MoNE), 2009a). \\
\hline Science & Comprehending the mutual interaction between humans and the environment. \\
& Keeping the immediate surroundings clean in order to prevent pollution of the \\
& environment (MoNE, 2013). \\
\hline Social Sciences & Making distinction of the natural and human elements seen in the surrounding \\
& environment (MoNE, 2005). \\
\hline Mathematics & Creating bar charts. \\
Interpreting bar charts (MoNE, 2009b). \\
\hline Public
\end{tabular}

As seen in Table 16, while the gains in Turkish and mathematics disciplines have been written specific to the disciplines, gains in the science and social studies disciplines have been written within the context of environment. This is because the curriculums of science and social studies disciplines contain gains about environment education. Since Public Administration discipline does not exist as a course in 
primary schools, the gains have been determined by the related group advisor, and finalized after discussion with other advisors.

In the third stage where the community service is carried out, the seminars have been conducted as stated in Table 15. The course plans presented by each group in the seminars can be summarized as follows:

- Turkish: Watching a drama piece about basic concepts on air pollution; guessing the meaning of words from what the students listen to; making deductions and comparisons from what they listen to; examining images about basic concepts and improving vocabulary by making use of these images; trying to solve puzzles about basic concepts; researching the meanings of newly encountered words during this stage.

- Science: Making experiments in order to observe air pollution; discussing the effects of the results of the experiment on the health of living beings, together with the human causes and effects of air pollution; watching and discussing related animation on the subject; taking note of the importance of mutual interaction between humans and the environment.

- Social Studies: Explaining the natural and human causes and effects of air pollution by including drama pieces and visual materials about the natural and human elements related to the causes and effects of air pollution.

- Mathematics: Investigating the data of air pollution from previous years in our city; creating and interpreting bar charts using these data; solving problems aimed at predicting the future status with the help of the charts.

- Public Administration: Watching drama pieces about national laws and regulations, international conventions made for prevention of air pollution, comparisons of the status of air pollution between different countries; watching and discussing interviews about the public opinion.

Finally, APAQ-III and KWL form have been applied to pre-service teachers as post-tests. In addition, two randomly selected pre-service teachers have been interviewed and the main study has been finalized.

\section{Conclusions and Recommendations}

In this project, an interdisciplinary learning/teaching environment for CSPC has been designed aimed at sixth semester students in the department of primary education. The learning/teaching environment consists of partly activities carried out in the department, and partly activities carried out in primary schools.

The activities carried out in the department under the theme of air pollution involve preparation of course plans under focus points in five different disciplines that can be used in order to explain air pollution to students. These disciplines are Turkish, Social Studies, Science, Mathematics and Public Administration. Pre-service teachers appointed to each discipline work on focus points such as basic concepts, causes and effects, precautions for the future within the context of their fields. The created focus point/discipline groups share their work within the department, and thus not only they learn by themselves, but also have the chance to learn from each other. Hence a pre-service teacher in a discipline group has the opportunity to participate in the examination and evaluation process of the studies on air pollution conducted by pre-service teachers from other groups. Therefore the pre-service teachers have the chance to study the subject of air pollution with an interdisciplinary approach. In addition, they acquire experience on preparing course plans for both socio-scientific issues and interdisciplinary learning environments.

During the part of the activities carried out in the primary schools, the pre-service teachers put their course plans in practice and make presentations in different schools. Hence, not only pre-service 
teachers, but also the students gain interdisciplinary information and awareness about air pollution. Moreover, the pre-service teachers gain experience on how to make interdisciplinary associations.

These kinds of projects that can be conducted within the scope of CSPC enable the pre-service teachers to obtain awareness on a social issue, and to find the opportunity to use and develop their professional knowledge. In the case of the results of the study indicating increase in the awareness on air pollution, further similar activities can be developed within the scope of CSPC, and awareness raising studies on socio-scientific issues can be conducted for students and the society. The results of this study can be used by the university faculties who are advisors for CSPC and teachers who plan to carry out community service activities in their schools for the interdisciplinary planning of the contents. Thus the opportunity would be provided for the pre-service teachers and students to analyze and evaluate a subject with the perspective of various different disciplines just like in the real life, rather than learning the subject through the perspective of just one discipline.

\section{Acknowledgments}

This work was supported by Scientific Research Projects of Giresun University (Project number: EĞTBAP-A-250414-33, 2014). The preliminary version of this study was presented in International In-Service Programme and Symposium in Ankara-Turkey in 2015 (Interdisciplinary Community Service Practices in Teacher Training: Air Pollution Awareness) and published in the abstract book of symposium. 


\section{Türkçe Sürümü}

\section{Giriş}

Öğretmenler eğitim sisteminin toplumu etkileyen en önemli parçasıdır. Toplumla bütünleşme, topluma lider olma gibi görev ve sorumlulukları nedeniyle, öğretmenler mesleğe başlamadan önce bu yönlerini geliştirecek eğitimler almalıdır. Bu eğitimler sırasında da deneyimler kazanmaları önemli görülmektedir (Çetin \& Sönmez, 2009). Türkiye'de eğitim fakültelerinde zorunlu ders olarak yer alan Topluma Hizmet Uygulamaları Dersi (THUD) öğretmenlerin bu deneyimleri kazanabilecekleri bir derstir (Gökçe, 2012). Benzer uygulamalar farklı ülkelerde de görülmekte ve sadece öğretmen eğitimi kapsamında yürütülmemektedir (Beldağ, Yaylacı, Gök \& İpek, 2015). Örneğin Amerika'da ServiceLearning (Hizmet Ederek Öğrenme) olarak adlandırılan ve K-12'den üniversite öğrencilerine kadar herkesi kapsayan bir uygulama bulunmaktadır (Barton, 2000). Hizmet Ederek ÖğrenmeJohn Dewey'in "deneyime" vermiş olduğu öneme dayanmaktadır (Giles \& Eyler, 1994; You \& Rud, 2010). Öğretmen eğitimi içerisinde Hizmet Ederek Öğrenmeise hem öğretmen adaylarının hem de öğretmenlerin karmaşık sosyal problemlere ilişkin deneyim kazanması, sosyal beceri geliştirmesi, sosyal kültür ve değerleri tanıması olarak değerlendirilmektedir (Barton, 2000).

THUD; topluma hizmetin önemi, toplumsal sorunları belirleme, sorunların çözümüne yönelik projeler hazırlama, toplumsal konularla ilgili seminer, panel gibi bilimsel etkinliklere izleyici, konuşmacı ya da düzenleyici olarak katılmayı içermektedir (YÖK, 2006). Bu dersle, sadece geleceğin öğretmenlerinin toplumsal konularda bilgilerini arttırmak değil aynı zamanda mesleklerinin toplumsal gelişim açısından öneminin farkına varmalarını sağlamak hedeflenmektedir(Gökçe, 2012). Bunun yanı sıra öğretmen adaylarının gelecekte mesleklerini icra ederken öğrencileriyle birlikte topluma hizmet çalışmalarını nasıl gerçekleştirebilecekleriyle ilgili temel bilgi ve becerileri kazanmaları dersin hedefleri arasında yer almaktadır (Küçükoğlu, 2012; Özdemir \& Tokcan, 2010).

THUD ile hedeflenen kazanımlara ulaşmak için hazırlanan ders planları kuramsal bir temele oturtulmalı, uygulama ve değerlendirme süreçleri öğretim programlarına uygun organize edilmeli ve mümkün olduğunca çok paydaşlı bir öğrenme ortamı düzenlenmelidir (Küçükoğlu, 2012). Bazı araştırmacılar THUD’nin planlaması, kapsamının belirlenmesi, zamanlaması ve öğretim elemanlarının yeterli rehberlik yapamaması gibi çeşitli sorunların yaşandığına dikkat çekmiştir (Arcagök \& Şahin, 2013; Gökçe, 2011; Küçükoğlu, Korkmaz, Köse \& Taşgın, 2014). Bu sorunların önüne geçebilmek ve dersin hedeflerine ulaşabilmek için, iyi planlanmış ve olası sonuçları ön görülebilen uygulamaların yapılması önemlidir. Literatürde öğretmen adaylarının THUD’ne ilişkin görüşlerinin tespit edildiği (Arcagök\& Şahin, 2013; Çetin \& Sönmez, 2009; Gökçe, 2011; Sönmez, 2010) ve bu görüşler doğrultusunda dersin değerlendirildiği (Ekşi \& Cinoğlu, 2012; Kesten, 2012; Özdemir \& Tokcan, 2010) araştırmalara rastlanmıştır. Bununla birlikte THUD kapsamında yapılan uygulamaların hem öğretmen adaylarına hem de hizmetin sunulduğu hedef kitleye etkisinin araştırılması da gerekmektedir. Bu doğrultuda THUD kapsamında yapılacak olan uygulamaların etkilerini ortaya çıkarmak, gelecekte yapılacak uygulamaların planlanabilmesi için tüm paydaşlara yol gösterici olacaktır.

THUD kapsamında yapılacak uygulamalar doğru planın yapılması ve uygun konuların belirlenmesiyle başlar. Dezavantajlı kesimlerin desteklenmesi, çevrenin koruması ve ürün kalitesi gibi konular bu ders kapsamında ele alınabilir (Yılmaz, 2011). Ayrıca sosyal hizmet kurumları ile çalışmalar yürütme, çeşitli kurumları fiziki olarak geliştirme, çevre bilinci ve toplumsal cinsiyet bilinci oluşturma gibi etkinlikler de yapılmaktadır (Yılmaz, 2011). Bu etkinlikler incelendiğinde, toplumsal sorunlara çözüm üretme amacında oldukları görülmektedir. Bu tür toplumsal sorunların genellikle sosyobilimsel olarak ele alınması gerekmektedir (Topçu, 2015). Çünkü sosyobilimsel sorunlar farklı disiplinlere ait bilgi ve becerilerin bir arada işe koşulmasıyla çözülebilir. Bu nedenle THUD kapsamında dersin amacına uygun olarak öğretmen adaylarına ve hedef kitleye ilişkili disiplinlerin bilgi ve becerisini edinebilecekleri sosyobilimsel odaklı öğrenme ortamları sağlanabilir. 
Öğretim programları incelendiğinde sıklıkla karşılaşılabilecek sosyobilimsel konulardan biri de çevre sorunlarıdır. Çevreyle ilgili yaşanan olumsuzlukların farkında olan ve bu olumsuzluklara karşı harekete geçen bireylerin yetişmesi toplumsal açıdan önemlidir (Şahin, Cerrah, Saka\& Şahin, 2004). Bu bağlamda THUD kapsamında çevre sorunlarının çözülmesinde öğretmen adayları aktif rol alabilirler (Gökçe, 2012). Çevre sorunları küresel ısınma, iklim değişikliği, biyolojik çeşitliliğin korunamaması, canlı sağlığının korunamaması, toprak, su ve hava kirliliği gibi içinde bulunduğumuz yüzyılda karşı karşıya gelinen pek çok sorunu kapsamaktadır.

Çevre sorunlarıyla ile ilgili literatürde çok sayıda çalışma vardır. Ancak bu çalışmalarda genellikle çevre sorunlarına yönelik bilgi, farkındalık ve tutumlarının incelendiği (Köklükaya\& Yildirim, 2016; Öztürk, 2002; Şahin, 2013; Şahin, Ertepınar\& Teksöz, 2012) ve bu sorunların da farklı disiplinlerde eğitim alan bireylerin görüşlerinin ele alındığı görülmektedir (Demirkaya, 2006, Seçgin, Yalvaç\& Çetin, 2010; Selvi \& Yıldız, 2009). Çünkü çevre bilimi tek başına bir disiplin olmaktan öte disiplinler arası olarak nitelendirilmektedir (Demirkaya, 2006; Yılmaz, Morgil, Aktuğ\& Göbekli, 2002). Hava kirliliği de diğer çevre sorunları gibi birden fazla disiplinle ilgili bilgi ve yöntemlerin bir arada kullanılmasıyla çözülebilecek bir sorundur (Uzgören\& Yücel, 1999). Bu çalışmada da THUD kapsamında uygulanmış hava kirliliği temalı disiplinler arası bir projenin tanıtımı yapılmaktadır. Projenin tanıtımına başlamadan önce, disiplinler arası yaklaşım konusunda kısa bir bilgi vermenin faydalı olacağı düşünülmektedir.

\section{Disiplinler Arası Yaklaşım}

Disiplinler arası yaklaşım, bir tema, problem, konu veya olayı incelemek için birden fazla disipline ait yöntemin bilinçli olarak birlikte kullanıldığı bilgiye bakış ve öğretim yaklaşımıdır (Jacobs, 1989). Birden fazla disiplini ilişkilendirerek bir temada bütünleştirildiği için tematik yaklaşım olarak da anılmaktadır (İşler, 2004).

Disiplinler arası yaklaşımın öğretme/öğrenme ortamlarında kullanımıyla ilgili işbirlikçi, tamamlayıcı, karma, tümleyici, birleşik, katılımcı, sistem odaklı, geniş kapsamlı, problem odaklı, bütüncül, multidisipliner, interdisipliner ve transdisiplinergibi çok sayıda kavram karşımıza çıkmaktadır (Tress, Tress\& Fry, 2005). Smith (2006), bu çeşitliliğin nedenini yaklaşımı ele alan ve disiplinleri birleştirecek kişiye/eğitimciye bağlamaktadır. Bu durum her uygulama için farklı bir kavramın tanımlanabileceği anlamına gelse de birçok araştırmacının bu kavramları sınıflandırma yoluna gittikleri görülmektedir (Drake \& Burns, 2004; Fogarty, 1991; Lederman \& Niess, 1997; Petrie, 1992). Öğretimde kullanılan sınıflandırmaların çoğunda ise multidisipliner, interdisipliner ve transdisipliner yaklaşımlarına yer verilmektedir.

Multidisipliner yaklaşımda, farklı disiplinler/dersler aynı temaya ait odaklarda ayrı ayrı işlenir ve bu disiplinlere ait bilgi ve yöntemler tema yoluyla bir araya getirilir (Drake \& Burns, 2004; Grady, 1994). Böylece disiplinin öğrenilebilmesi için seçilen odaklar birleşerek temayı oluşturmaktadır. Burada esas olan disiplini öğrenmekken tema disiplinlerin öğrenilebilmesi için bir bağlam görevi görür.

Interdisipliner yaklaşım, bir temanın öğrenilebilmesi için farklı disiplinlerin ve disiplinlere uygun odakların aynı derslerde yeni bilgi üretmek veya çapraz bağlar oluşturmak yoluyla bir arada ele alındığı yaklaşımdır (Grady, 1994; Tress, Tress\& Fry, 2005, 2007). Burada esas olan temayı öğrenmekken disiplinler temanın farklı boyutlarının anlaşılabilmesi için yardımcı vazifesindedir.

Transdisipliner yaklaşım ise, belli bir temanın temayı ilgilendiren farklı disiplinlerdeki kurum veya kuruluşların (örneğin, arazi yöneticileri, kullanıcı grupları, genel halk) katılımı ve bakış açıları ile ele alınmasıdır (Tress, Tress \& Fry, 2006).

Lederman ve Niess (1997) intedispliner yaklaşımın multidisipliner yaklaşımdan farkını açıklarken çorba analojisinden yararlanmıştır. Multidisipliner yaklaşımı heterojen yapıdaki şehriyeli tavuk çorbasına benzeten araştırmacılar, interdisipliner yaklaşımı ise bileşenleri (disiplinler) birbirinden ayırt edilemeyen homojen yapıda bir karışım olan domates çorbasına benzetmektedirler. Bir tema multidisipliner yaklaşımda ele alındığında farklı farklı derslerde birbirinden bağımsız olarak işlenir ve her dersin 
amacı/kazanımları ayrı ayrı fark edilir. Fakat bir tema interdisipliner yaklaşımla ele alındığında, temayı öğrenmeye ilişkin odaklar ilgili olduğu disiplinlerin/derslerin kazanımları ile ele alınırken, disiplinler ayrı olarak ele alınmaz. Transdisipliner yaklaşım ise, interdisipliner yaklaşıma bu yönüyle benzer bir yaklaşımdır. İkisi arasında temel fark transdisipliner yaklaşımda, ele alınan bir tema, gerçek yaşama uyarlanır ve ürün ortaya çıkarılır.

\section{Projenin Önemi ve Amacı}

Öğrencilerin ve öğretmen adaylarının hava kirliliği konusu ile ilgili bilgi düzeylerinin düşük ve bilimsel bakış açısından yoksun olduğu çeşitli araştırmalarla ortaya koyulmuştur (Boyes, Stanisstreet \& Yeung 2004; Darçın \& Sert-Çıbık, 2009; Thornber, Stanisstreet \& Boyes, 1999). Oysa hava kirliliği ilgili sorunların çözülmesi için bireylerin bilgi düzeylerinin ve farkındalıklarının arttırılması önem arz etmektedir (Demirbaş \& Pektaş, 2009). Toplumda bireylerin yetiştirilmesi konusunda ailelerden sonra en önemli sorumluluk öğretmenlere düşmektedir. Bu nedenle de öğretmenler sosyobilimsel konularla ilgili sorunları tespit edebilmeli, öğrencilerini ve halkı bilinçlendirebilecek etkinlikler düzenleyerek farkındalık sahibi bireylerin yetişmesini sağlayabilmelidir (Seçgin, Yalvaç \& Çetin, 2010). Bu bağlamda, öğretmen eğitiminde topluma hizmet içerikli etkinliklerin yer alması ve öğretmen adaylarının topluma hizmetle ilgili deneyim kazanmaları önemli bir husustur. Böylece öğretmen olduklarında mevcut deneyimlerinden faydalanarak, okul ve çevresindeki sorunları tespit etmeye ve bunların çözümü için birtakım çalışmalar yapmaya hazırlıklı olacakları düşünülmektedir.

Hava kirliliği gibi sosyobilimsel konularda yapılan çalışmaların bilgilendirmeden öteye geçerek farkındalık kazandırma boyutunda işlenebilmesi için uygulamalı etkinlikler gerçekleştirilmelidir (Önal \& Güngördü, 2008). Bunun sağlanabilmesi için ise öğretmen adaylarına sosyobilimsel konuları interdisipliner bir yaklaşımla ele alma konusunda deneyim kazanacakları öğrenme ortamlarının tasarlanması önemlidir. Bu öğrenme ortamlarının tasarlanabileceği derslerden biri de "toplumun güncel sorunlarını belirleme ve çözüm üretme (YÖK, 2006)" ve "topluma hizmet çalışmalarının okullarda uygulanmasına yönelik temel bilgi ve becerilerin kazanılması (YÖK, 2006)” gibi amaçları olan THUD'dir.

Bu projede de THUD kapsamında öğretmen adaylarının bir yandan hava kirliliği farkındalığı bir yandan da disiplinlerarası öğretim ile ilgili mesleki deneyim kazanacakları düşünülmektedir. Öğretmen adaylarının edindikleri bu kazanımlardan faydalanarak gelecekteki öğrencilerine de farkındalık kazandırabilmeleri önemlidir. Bu proje kapsamında yapılan etkinliklerin sadece öğrencilerin değil, aynı zamanda öğrenciden aileye, aileden topluma akış yönünde daha büyük kitlelerin hava kirliği hakkında farkındalık kazanmalarını sağlayacağı umulmaktadır. Bu bağlamda THUD’nin amacına uygun bir içerik oluşturma üzerinde çalışılan proje kapsamında öğretmen adaylarına edindikleri bilgi ve farkındalığı gelecekte kendi hitap edecekleri seviyedeki öğrencilere aktarabilmeleri için fırsat sağlanmıştır. Bu nedenle proje kapsamında yapılan etkinliklerin hem öğrencilerde hem de öğretmen adaylarında iki yönlü olarak incelenmesi önem arz etmektedir. Ayrıca çalışmanın THUD içeriği geliştirecek öğretim üyelerine, topluma hizmet uygulamaları yapacak veya disiplinlerarası yaklaşımla ders işleyecek öğretmen ve öğretim üyelerine yol gösterici olacağı düşünülmektedir. Bu bağlamda bu araştırmanın amacı THUD kapsamında yürütülen hava kirliliğiyle ilgili disiplinlerarası bir projeyi tanıtmaktır.

\section{Projenin Tasarlanması, Geliştirilmesi ve Uygulama Süreci}

Projenin tasarlanması, geliştirilmesi ve uygulanmasında izlenen süreç ve sürece ait her basamakta yürütülen çalışmaları gösteren akış şeması Şekil 1'de verilmiştir. 


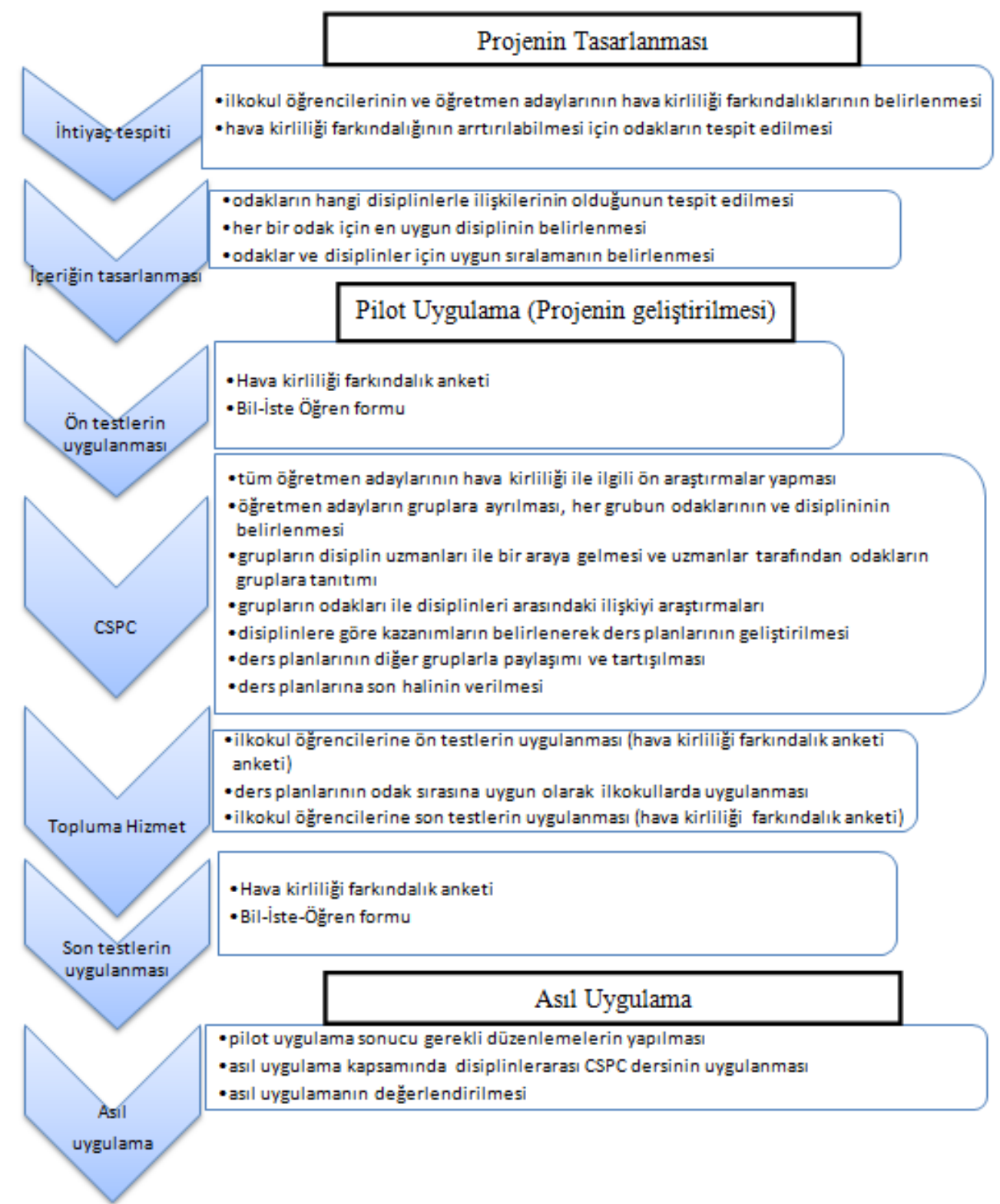

Şekil 1. Projenin tasarlanma ve yürütülme sürecinde yapılan çalışmalara ait akış şeması

Araştırmada öncelikle öğrenci ve öğretmen adaylarının hava kirliliğine yönelik mevcut farkındalıkları ve geliştirilmeye ihtiyaç duyulan farkındalıklarını belirlemek amacıyla ihtiyaç analizi yapılmıştır (Şekil 1). Bu analizi takiben disiplinlerarası yaklaşım benimsenerek bir öğrenme ortamı tasarlanmıştır. Tasarlanan öğrenme ortamının pilot uygulaması, ön-son test sonuçlarının karşılaştırılması ile değerlendirilmiştir. Pilot uygulamanın ardından asıl uygulama gerçekleştirilmiş ve değerlendirme yine ön-son test sonuçlarının karşılaştırılması ile yapılmıştır.

Projenin tasarlanması, geliştirilmesi ve uygulanma sürecinde araştırmacılar hem araştırmacı hem de disiplin uzmanı olarak görev almıştır. Proje sürecinde gerçekleştirilmiş olan çalışmalar akış şemasına uygun olarak, ilerleyen bölümlerde ayrıntılı olarak tanıtılmıştır. 


\section{Projenin Tasarlanması}

Projenin tasarım aşamasında öncelikle hava kirliliği farkındalığının kazandırılmasında önemli olan odak noktaları belirleyebilmek için bir ihtiyaç analizi yapılmıştır. Bunun için araştırmacılar tarafından hazırlanan Hava Kirliliği Farkındalık Anketi (HKFA) 32 öğretmen adayına ve 120 ilköğretim dördüncü sınıf öğrencisine uygulanmıştır (Tablo 1). Bu öğretmen adaylarının yer aldığı grup bir eğitim fakültesinde THUD’ni alan dört grup arasından kura ile belirlenmiştir. Öğretmen adaylarının uygulama sürecinde kolay ulaşabilmeleri için de aynı ildeki ilkokullardan rastgele seçilen dört okulda öğrenim gören ilköğretim öğrencileri çalışmaya dahil edilmiştir. HKFA'da hava kirliliğinin tanımı, nedenleri, sonuçları ve kirliliği önlemek içi neler yapılabileceği ile ilgili dört ortak soru hem öğretmen adaylarına hem de dördüncü sınıf öğrencilerine sorulmuştur. Öğretmen adaylarına ayrıca hava kirliliği ile ilgili ulusal ve uluslararası yaptırımlar, bulundukları şehirde hava kirliliği olup olmadığı ve varsa onları nasıl etkilediği, hava kirliliğini önlemek için neler yaptıkları ya da yapmak isteyecekleri olmak üzere dört farklı soru daha sorulmuştur. İlkokul öğrencilerinin gelişim seviyelerine göre uzun anketleri doldururken sıkılabilecekleri ve yarıda bırakabilecekleri düşünülerek ilkokul öğrencilerine öğretmen adaylarından daha az soru sorulmuştur. Hazırlanan anket sorularına yönelik Sınıf Öğretmenliği alanında uzman iki araştırmacıdan görüş alınmıştır. Uzman görüşleri doğrultusunda öğrencilerin ve öğretmen adaylarının bilişsel gelişim seviyelerine uygun olarak sorular belirlenmiştir (Tablo 1).

Tablo 1.

ihtiyaç Analizi için Kullanılan HKFA'de Yer Alan Sorular, Amaçları ve Sorulduğu Gruplar.

\begin{tabular}{|c|c|c|}
\hline Soru & Amaç & Grup \\
\hline Sizce hava kirliliği nedir? & $\begin{array}{l}\text { Hava kirliliği farkındalığının genel bir } \\
\text { bakış açısıyla belirlenmesi }\end{array}$ & $\begin{array}{l}\text { Öğretmen adayları, } \\
\text { öğrenciler }\end{array}$ \\
\hline $\begin{array}{l}\text { Hava kirliliğinin nedenleri neler } \\
\text { olabilir? }\end{array}$ & $\begin{array}{l}\text { Hava kirliliğinin nedenleri ile ilgili } \\
\text { farkındalığı belirleme }\end{array}$ & $\begin{array}{l}\text { Öğretmen adayları, } \\
\text { öğrenciler }\end{array}$ \\
\hline $\begin{array}{l}\text { Hava kirliliğinin sonuçları neler } \\
\text { olabilir? }\end{array}$ & $\begin{array}{l}\text { Hava kirliliğinin sonuçları ile ilgili } \\
\text { farkındalığı belirleme }\end{array}$ & $\begin{array}{l}\text { Öğretmen adayları, } \\
\text { öğrenciler }\end{array}$ \\
\hline $\begin{array}{l}\text { Hava kirliliğini önlemek için neler } \\
\text { yapılmalıdır? }\end{array}$ & $\begin{array}{l}\text { Hava kirliliğine yönelik önlemler ile } \\
\text { ilgili farkındalığı belirleme }\end{array}$ & $\begin{array}{l}\text { Öğretmen adayları, } \\
\text { öğrenciler }\end{array}$ \\
\hline $\begin{array}{l}\text { Hava kirliliği ile ilgili ulusal ve } \\
\text { uluslararası yaptırımlar ve } \\
\text { içerikleriyle ilgili neler biliyorsunuz? }\end{array}$ & $\begin{array}{l}\text { Hava kirliliğine yönelik önlemler ile } \\
\text { ilgili farkındalığı belirleme }\end{array}$ & Öğretmen adayları \\
\hline $\begin{array}{l}\text { Giresun'da hava kirliliği olduğunu } \\
\text { düşünüyor musunuz? Cevabınızı } \\
\text { sebepleriyle açıklayınız. }\end{array}$ & $\begin{array}{l}\text { Yakın çevresindeki hava kirliliği ile ilgili } \\
\text { farkındalığı belirleme }\end{array}$ & Öğretmen adayları \\
\hline $\begin{array}{l}\text { Giresun'da hava kirliliği varsa sizi ve } \\
\text { çevrenizi nasıl etkiliyor? Açıklayınız. }\end{array}$ & $\begin{array}{l}\text { Yakın çevresindeki hava kirliliğinin } \\
\text { sonuçları ile ilgili farkındalığı belirleme }\end{array}$ & Öğretmen adayları \\
\hline $\begin{array}{l}\text { Hava kirliliğini önlemek ya da } \\
\text { azaltmak için siz neler yapıyorsunuz } \\
\text { ya da yapmak istersiniz? }\end{array}$ & $\begin{array}{l}\text { Hava kirliliğini önlemek için kendisinin } \\
\text { neler yapabileceği ile ilgili farkındalığı } \\
\text { belirleme }\end{array}$ & Öğretmen adayları \\
\hline
\end{tabular}

Öğretmen adaylarının verdiği cevaplar iki ayrı araştırmacı tarafından kodların belirlenmesi ve temaların oluşturulması aşamalarından geçerek analiz edilmiştir. Kodlamalar sırasında öğrencilerin ifadelerinde belirlenen kodların hangi tema altında kodlanabileceği hususunda araştırmacılar fikir birliğine varamadığında, çevre sorunlarıyla ilgili çeşitli kitaplara (Güney, 2004; Özey, 2009) başvurulmuş ve karar verilmiştir. Araştırmacılar kendi aralarında gerçekleştirdikleri tartışmalar sonucu uyum sağlayarak analizi tamamlamıştır. Güvenirlik için öğrencilerin cevapları da öğretmen adayları için oluşturulmuş olan temalarla ve kodlarla karşılaştırma yaparak yine iki ayrı araştırmacı tarafından analiz 
edilmiştir. Bir öğrenci birden fazla kod yazabileceği için aynı öğrenci farklı kodlarda ya da temalarda yer alabilmektedir. Yapılan analizler sonucu elde edilen bulgular aşağıda sunulmuştur.

Hava kirliliğinin tanımı ile ilgili birinci soruya öğretmen adaylarının ve öğrencilerin vermiş oldukları cevaplar Tablo 2'de sunulmuştur.

Tablo 2.

Hava Kirliliğinin Ne Olduğu ile ilgili Soruya Verilen Cevaplar.

\begin{tabular}{llcccc}
\hline Tema & Kod & ÖA $^{*}$ & ÖA(\%) & Ö* & Ö(\%) \\
\hline Neden & Temiz havanın kirlenmesi & 3 & 09.68 & 49 & 43.36 \\
& Beşeri faaliyetler & 8 & 25.81 & 31 & 27.43 \\
& Zararlı gazların havaya karışması & 13 & 41.94 & 29 & 25.66 \\
& Zararlı gaz oranın artması & 6 & 19.35 & 5 & 04.42 \\
& Doğal ve beşeri faaliyetler & 3 & 09.68 & 1 & 00.88 \\
& Doğal faaliyetler & - & - & 1 & 00.88 \\
& Kirleticilerin artması & 2 & 06.45 & - & - \\
\hline Sonuç & Canlılara zarar & 5 & 16.13 & 5 & 04.42 \\
& Doğaya zarar & - & - & 3 & 02.65 \\
& Doğaya ve canlılara zarar & 2 & 06.45 & 2 & 01.77 \\
& Doğanın kendini yenileyememesi & 2 & 06.45 & - & - \\
\hline
\end{tabular}

*ÖA: Öğretmen adayı, Ö: Öğrenci

Atmosferde bulunan gaz ve partiküllerin insanlar, diğer canlılar ve eşyalara zarar verici miktarda yükselmesine hava kirliliği denir (URL - 1). Diğer bir ifadeyle hava kirliliği atmosferdeki zararlı gaz ve partiküllerin oranındaki artıştır (Özey, 2009). Öğretmen adayları ve öğrenciler ise hava kirliliğini nedenleri ya da sonuçları ile açıklamaya çalışmışlardır (Tablo 2). Öğretmenlerin verdiği cevaplar incelendiğinde zararlı gazların havaya karışması kodunun \%41.94 oranla en fazla belirtilen neden olduğu belirlenmiştir. Beşeri faaliyetler kodu da oldukça sık belirtilmiştir (\%25.81). Öğrencilerde ise temiz havanın kirlenmesi kodu \%43.36'lık bir oranla en sık karşılaşılan kod olmuştur. Öğrencilerde sık karşılaşılan kodlar arasında beşeri faaliyetler (\%27.43) ve zararlı gazların havaya karışması (\%25.66) da yer almaktadır. İnsan için zararlı kabul edilen gazlar havada sürekli bulunmaktadır. Ancak hava kirliliği için bu gazların oranındaki artışı önemlidir (Özey, 2009). Bu nedenle öğretmen adaylarınca ve öğrencilerce sıklıkla ifade edilen zararlı gazların havaya karışması kodu doğru kabul edilemez. Öğrencilerin çoğu tarafından ifade edilen temiz havanın kirlenmesi kodu ise bir tanımlamadan öte kelime oyunuyla açıklama niteliğindedir. Bu bağlamda öğrencilerin "kirlilik" olarak algıladıkları durumun tespit edilmesi mümkün olmadığı için bu kodun doğru/bilimsel kabul edilemeyeceği açıktır. Öğrencilerin büyük bir kısmının bu kodla ilgili açıklamalar yapması hava kirliliğini tanımlamak konusunda zorluk yaşadığının göstergesi olabilir. Her iki grup tarafından sıklıkla ifade edilen kodlardan biri olan beşeri faaliyetler kodu ise iki grubun da insanların hava kirliliği oluşmasında bir etkisinin olduğunun farkında olduğunu ortaya çıkarmaktadır.

Hava kirliliğinin ne olduğunu hava kirliliğinin sonuçlarıyla açıklamaya çalışan öğretmen adayları ve öğrenciler ise kirliliğin çeşitli zararlarından bahsetmiştir. Önal ve Güngördü (2008)'nün sosyal bilgiler öğretmenliği son sınıf öğrencileriyle yaptığı çalışmada da, öğretmen adaylarının büyük bir kısmı kirli havayı "canlı organizmaların hayat şartlarına olumsuz etkiler yapabileceği durum" olarak tanımlamıştır. Nedenlerinden faydalanarak hava kirliliğini açıklama çabalarında da zararlı gaz ifadeleri karşımıza çıkmaktadır. Hava kirliliği ile ilgili yapılan çeşitli tanımlar da incelendiğinde kirliliğin canlılara ve doğaya zararlarından bahsedildiği görülmektedir. Bu araştırma için kabul edilmiş tanımda ise 'atmosferdeki zararlı gaz ve partiküllerin oranındaki artış' ifadesinde 'zararlı gaz ve partiküller' hava kirliliğinin canlılar için zararlı olma kriteri ile ilgilidir. Ancak her iki grubun da açıklamalarında ekonomik, kültürel ve 
psikolojik etkilerine yer vermeden sadece canlı organizmalar üzerinden açıklama yapmaya çalışış olmaları bu gibi zararların farkında olmadıkları ihtimalini ortaya çıkarmaktadır.

Hava kirliliğinin nedenleri ile ilgili ikinci soruya öğretmen adaylarının ve öğrencilerin vermiş oldukları cevaplar Tablo 3'de sunulmuştur.

Tablo 3.

Hava Kirliliğinin Nedenleri ile ilgili Soruya Verilen Cevaplar.

\begin{tabular}{llcccc}
\hline Tema & Kod & ÖA & ÖA(\%) & Ö & Ö(\%) \\
\hline Beşeri nedenler & Sanayi & 28 & 90.32 & 44 & 38.94 \\
& Motor & 20 & 64.52 & 38 & 33.63 \\
& Isınma & 17 & 54.84 & 33 & 29.20 \\
& Atık & 6 & 19.35 & 21 & 18.58 \\
& Sigara & - & - & 9 & 07.96 \\
& Beşeri faaliyetler & 3 & 09.68 & 5 & 04.42 \\
& Ormanları yok etme & 1 & 03.23 & 4 & 03.54 \\
& Kişisel bakım & 8 & 25.81 & 1 & 00.88 \\
& Eğitimsizlik & 1 & 03.23 & 1 & 00.88 \\
& Çarpık kentleşme & 2 & 06.45 & - & - \\
& Ağaçlandırma yetersizliği & 2 & 06.45 & - & - \\
& Orman yangını & 2 & 06.45 & - & - \\
& Sera gazları & 2 & 06.45 & - & - \\
& Yangınlar & 1 & 03.23 & - & - \\
\hline Doğal nedenler & Volkan & 5 & 16.13 & - & - \\
& Deprem & 1 & 03.23 & - & - \\
\hline
\end{tabular}

Öğretmen adaylarının hava kirliliğinin nedenleri ile ilgili soruya verdikleri cevaplar beşeri ve doğal nedenler temalarında toplanmış olmasına rağmen öğrencilerin verdikleri cevapların tamamı beşeri nedenler temasına yerleşmiştir (Tablo 3). Bu durum öğrencilerin doğal nedenlerle de havanın kirlenebileceğinin farkında olmadığını göstermektedir. Hem öğrencilerin hem de öğretmen adaylarının çoğu beşeri nedenlerden sanayi, motor, ısınma ve atık kodlarına değinmişlerdir. Öğretmen adaylarının \%90.32'si sanayiden bahsederken, öğrencilerin \%44'ünün sanayiden bahsetmiş olması öğretmen adaylarına göre sanayinin kirlemede daha önemli bir faktör olduğu düşüncesini ortaya çıkarabilir. Öğretmen adaylarının \%64'ü ve öğrencilerin \%33'ü ise motorla ilgili koda değinmişlerdir. Bu kodda özellikle araba motorları nedeniyle salınan egzoz gazlarından bahsetmektedirler. Benzer şekilde Thornber, Stanisstreet ve Boyes (1999)'in çalışmasındaki 10-11 yaşındaki öğrencilere göre de taşıma ve endüstri hava kirliliğinin en önemli sebepleridir.

Hava kirliliği denince akla yalnızca açık ortam hava kirliliği gelebilir. Oysa öğrencilerinde sigarayı da havanın kirlenmesi için bir neden olarak görmesi, günlük hayatlarında sigaradan rahatsız olmaları, yakın çevrelerinde sigara içen birinin sigara içmek için balkon gibi açık ortamları tercih ettiğini gözlemlemesi ya da sigaranın kapalı ortam hava kirliliğinin sebebi olduğunun farkında olduklarını gösterebilir. Güllü (2013) sigaranın yanmasıyla oluşan partiküler maddelerin bulunduğu kapalı ortamda hava kirliliğine sebep olabileceğini ifade etmiştir. Fakat atmosferdeki zararlı gazların oranındaki artışa etkisi çok büyük olmayacağı için açık ortam için hava kirliliği nedeni olarak ifade edilmemiş olabilir.

Hem öğretmen adayları hem de öğrenciler hava kirliliğinin oluşması için pek çok geçerli neden yazmışlardır. Ancak yazılmış olan nedenler incelendiğinde en yüksek oranda olanlarının mevcut durumda müdahale etmekte zorlanabilecekleri nedenler olduğu görülmektedir. Öğretmen adaylarının $\% 25^{\prime}$ inin değindiği kişisel bakım koduna ise öğrencilerin sadece $\% 00,88^{\prime} i$ değinmiştir. Bu durum öğrencilerin kişisel bakım ürünlerinin kullanımı nedeniyle hava kirliliğinin gerçekleşebileceğinin farkında olmadığını göstermektedir. 
Hava kirliliğinin sonuçları ile ilgili soruya öğretmen adaylarının ve öğrencilerin vermiş oldukları cevaplar Tablo 4'de sunulmuştur.

Tablo 4.

Hava Kirliliğinin Sonuçlarile ilgili Soruya Verilen Cevaplar.

\begin{tabular}{llcccc}
\hline Tema & Kod & ÖA & ÖA(\%) & Ö & Ö(\%) \\
\hline Canlı & Sağlık & 26 & 83.87 & 58 & 51.33 \\
& Hayvan & 3 & 09.68 & 8 & 07.08 \\
& Tüm canlılar & 4 & 12.90 & 7 & 06.19 \\
& Yaşam süresi & 1 & 03.23 & 6 & 05.31 \\
& Oksijenin azalması/olmaması & - & - & 6 & 05.31 \\
& Bitki & 5 & 16.13 & 5 & 04.42 \\
& Soy tükenmesi & 3 & 09.68 & 1 & 00.88 \\
& Sosyal yaşam & 1 & 03.23 & 1 & 00.88 \\
& İnsan & - & - & 1 & 00.88 \\
& Genetik bozulma & 1 & 03.23 & - & - \\
& Ruh sağlığı & 1 & 03.23 & - & - \\
\hline Çevre & Diğer fiziki çevre unsurlarının kirlenmesi & 6 & 19.35 & 12 & 10.62 \\
& Çevreyi kötü kokular sarması / havanın pis kokması & - & - & 10 & 08.85 \\
& Görüntü kirliliği & 2 & 06.45 & 6 & 05.31 \\
& Ozon tabakasının/atmosferin delinmesi & 4 & 12.90 & 4 & 03.54 \\
& Ekolojik denge & 4 & 12.90 & 2 & 01.77 \\
Iklim değişikliği & 4 & 09.68 & 1 & 00.88 \\
Küresel ısınma & 3 & 5 & 16.13 & 1 & 00.88 \\
Asit yağmurları & 1 & 03.23 & - & - \\
\hline
\end{tabular}

Öğretmen adaylarının ve öğrencilerin hava kirliliğinin sonuçları ile ilgili soruya verdikleri cevaplar canlı ve çevre temalarında toplanmıştır (Tablo 4). Canlı temasındaki sağlık kodu (\%83.87) en yüksek oranda değinilen kod olmuştur. Bu kodu çevre temasındaki diğer fiziki çevre unsurlarının kirlenmesi (toprak, su vb.) izlemektedir. Thornber, Stanisstreet ve Boyes (1999)'ın çalışmasında da öğrenciler (10-11 yaş) hava kirliliği nedeniyle bitki ve hayvanların öldüğünü, özellikle astım gibi sağlık sorunlarının ortaya çıktığını belirtmişlerdir. Dünya Sağlık Örgütü (WHO) de, 2012 verilerine göre dünyada yılda milyonlarca kişinin hava kirliğine bağlı nedenlerle öldüğünü rapor etmiştir (URL-2). Bu çalışmanın sağlık kodunun içinde de her iki grubun da çoğunlukla üst solunum yolları enfeksiyonlarından bahsettiği görülmüştür.

Canlı ve çevre teması altında yer alan "Soy tükenmesi, genetik bozulma, ruh sağlığı, ekolojik denge ve iklim değişikliği" gibi kodlara her iki grubun da çok az oranda değinmiş olması hava kirliliğinin uzun vadeli sonuçları konusunda farkındalıklarının düşük olduğunun göstergesi olabilir.

Benzer şekilde sosyal bilgiler öğretmen adayları da hava kirliliğinin açıkta bulunan tarihi eserlerin dokularının bozulması, insanlarda stres ve sinir sistemi bozukluklarının artması, solunum yolu enfeksiyonlarının artış göstermesi ve ulaşım araçlarının kaportalarının zarar görmesine yol açtığını belirtmişlerdir (Önal \& Güngördü, 2008). Thornber, Stanisstreet ve Boyes (1999)'in çalışmalarında da 1011 yaşındaki öğrencilerin çoğu binaların hava kirliliğinden olumsuz etkilendiğini ifade etmişlerdir. Ancak bu çalışmada hem öğretmen adayları hem de öğrenciler hava kirliliğinin ekonomik ve kültürel sonuçlarından bahsetmemişlerdir. Sadece bir öğretmen adayı hava kirliliğinin insan psikolojisini etkileyebileceğinden bahsetmiştir.

Öğrencilerin \%8.85'i havanın ya da çevrenin pis kokmasının hava kirliliğinin bir sonucu olduğunu belirtmiştir. Bu ifade öğrencilerin bir kısmının kirli havanın pis koktuğu gibi bir düşünceye sahip oldukları ihtimalini ortaya çıkarmaktadır. Oysa kirli hava pis kokmak zorunda değildir. Örnek vermek gerekirse, 
havayı kirleten azot oksitler $\left(\mathrm{NO}_{\mathrm{x}}\right)$ ve karbon monoksit $(\mathrm{CO})$ gibi gazlar kokusuzdur (URL-3). Benzer şekilde öğretmen adaylarının \%6.45'i, öğrencilerin ise \%5.31'i hava kirliliğinin görüntü kirliliğine neden olduğunu ifade etmiştir. Öğretmen adaylarının ve öğrencilerin bu ifadelerine rağmen hava kirli olduğunda havanın renginde bir farklılık olmak zorunda değildir. Örneğin, hava kirliliğine sebep olan azot oksitler $\left(\mathrm{NO}_{\mathrm{X}}\right)$, kükürt dioksit $\left(\mathrm{SO}_{2}\right)$, karbon monoksit $(\mathrm{CO})$ gibi gazlar renksizdir (URL-3). Sadık, Çakan ve Artut (2009)'ın çalışmalarında da 11-12 yaşındaki öğrencilerden hava kirliliği ile ilgili çizim yapmaları istendiğinde öğrencilerin gökyüzünü siyah ya da gri renkte boyadıkları görülmüştür. Bu durum öğrencilerin ve öğretmen adaylarının sadece kötü kokan ya da farklı renklerde olan hava tabakalarının bulunduğu yerlerde hava kirliliğinin olduğu gibi bir düşüncelerinin olma intimali nedeniyle dikkate değer bulunmuştur. Darçın ve Sert-Çıbık (2009) ile Boyes, Stanisstreet ve Yeung (2004) da fen bilgisi öğretmen adaylarının, kirli havanın kötü kokuya ya da renge sahip olacağı gibi alternatif kavramlara sahip olduklarını belirtmişlerdir.

Hava kirliliğini önlemek için neler yapılabileceği ile ilgili soruya öğretmen adaylarının ve öğrencilerin vermiş oldukları cevaplar Tablo 5'de sunulmuştur.

Tablo 5.

Hava Kirliliğinin Önlemek için Neler Yapılabileceği ile ilgili Soruya Verilen Cevaplar.

\begin{tabular}{llcccc}
\hline Tema & Kod & ÖA & ÖA(\%) & Ö & Ö(\%) \\
\hline Sanayi/Ev & Filtre & 20 & 64.52 & 57 & 50.44 \\
& Arıtma tesisi & - & - & 2 & 01.77 \\
& Baca temizliği & - & - & 1 & 00.88 \\
\hline Eğitim & Bilinçlendirme & 17 & 54.84 & 15 & 13.27 \\
& Kirletenleri uyarma & - & - & 4 & 03.54 \\
& Örgün eğitim & 2 & 06.45 & - & - \\
\hline Tarımsal & Ağaçlandırma/ağaçları kesmeme & 7 & 22.58 & 13 & 11.50 \\
faaliyet & ilaçlamayı azaltma & 1 & 03.23 & - & - \\
\hline Isınma & Fosil yakıt kullanımını azaltma & 7 & 22.58 & 2 & 01.77 \\
& Isı yalıımı & 1 & 03.23 & 1 & 00.88 \\
& Kaliteli kömür kullanımı & 5 & 16.13 & 1 & 00.88 \\
& Doğalgaz kullanımı & 2 & 06.45 & 1 & 00.88 \\
& Yakıtı bilinçli kullanma & - & - & 1 & 00.88 \\
\hline Devlet & Denetleme & 1 & 03.23 & - & - \\
politikaları & Şehir planlaması & 3 & 09.68 & - & - \\
& Durum tespiti, planlama & 2 & 06.45 & - & - \\
\hline Diğer & Toplu taşıma & 9 & 29.03 & 4 & 03.54 \\
& Gaz salınımını azaltma & - & - & 4 & 03.54 \\
& Sigarayı yasaklama & - & - & 3 & 02.65 \\
& Evi/ortamı havalandırma & - & - & 2 & 01.77 \\
& Doğayı koruma & - & - & 2 & 01.77 \\
& Kişisel bakım & 6 & 19.35 & 1 & 00.88 \\
& Orman yangınlarını önleme & - & - & 1 & 00.88 \\
& İcatlar yapılması & - & - & 1 & 00.88 \\
& Geri dönüşüm & 2 & 06.45 & - & - \\
\hline
\end{tabular}

Öğretmen adaylarının ve öğrencilerin çoğu, hava kirliliğini önlemek için neler yapılabilir sorusuna sanayi/ev temasında cevaplar vermiştir (Tablo 5). Öğretmen adaylarının \%64.52'si ve öğrencilerin \%50.44'ü filtre kullanımının gerekliliğinden bahsetmiştir. Burada bahsi geçen fabrika bacalarında ve ev bacalarında kullanılması gereken filtrelerdir. Benzer şekilde hava kirliliğinin nedenlerinin sorulmuş olduğu soruda da sanayi kodu en yüksek frekanslı kod olarak karşımıza çıkmaktadır. 
Hava kirliliğinin nedenleri konusunda hem öğretmen adayları hem öğrenciler eğitimsizlikten çok az bahsederken (Tablo 3); hava kirliliğini önlemek için neler yapılması gerektiği sorulduğunda öğretmen adaylarının \%54.84'ü, öğrencilerin ise \%13.27'si eğitim teması altındaki bilinçlendirme kodunda cevap vermişlerdir. Bilinçlendirme kodunun içinde kampanya, slogan, kamu spotu, seminer ve anket uygulamaları gibi çalışmalar yer almaktadır. Eğitim ve bilinçlendirme ile ilgili olan kodda öğretmen adaylarının öğrencilere göre daha çeşitli nedenler belirtmeleri, lisans yıllarında çevre ve çevre konuları ile ilgili aldıkları derslerin etkisiyle bir nebze daha farkındalıklarının üst düzeyde olmasına bağlanabilir.

Öğretmen adaylarının \%25’i hava kirliliğinin nedenleri arasında kişisel bakım ürünlerinden bahsederken sadece \%19.35'i kirliliği önlemek için bu ürünlerin kullanımlarının azaltılması gerektiğini belirtmiştir. Nedenler ve önlemler sorularında ise sadece bir öğrenci kişisel bakım ürünlerinden bahsetmiştir. Kişisel bakım ürünlerinin kullanımını azaltma bireysel bir faaliyet olmakla beraber başka hiçbir ek faaliyet gerektirmeden bireyin kendi başına doğaya vereceği zararı azaltması anlamına gelmektedir. Bu nedenle öğrencilerin bu konudaki farkındalığının düşük olduğu söylenebilir.

Hiç bir öğrencinin hava kirliliğini önlemek için devlet politikalarının geliştirilmesi gerekliliğini belirtmemiş olması, yaşlarının küçük olması ile açıklanabilir. Ancak, öğretmen adaylarının sadece \%19.36'sının bu temada cevap belirtmesi de, gelecek nesilleri etkileyebilecek hava kirliliği gibi bir çevre sorunu için devletin alacağı önlemler konusunda farkındalıklarının düşük olduğunu göstermektedir. Öğrencilerin gelişim dönemleri itibariyle devlet politikaları, ulusal ve uluslararası yaptırımlar hakkında bilgi sahibi olmaları beklenmemektedir. Bundan dolayı bu kapsamdaki sorular sadece öğretmen adaylarına sorulmuştur.

Hava kirliliği ile ilgili ulusal ve uluslararası yaptırımlar ve içerikleriyle ilgili soruya öğretmen adaylarının vermiş oldukları cevaplar Tablo 6'da sunulmuştur.

Tablo 6.

Hava Kirliliği ile ilgili Ulusal ve Uluslararası Yaptırımlar ve Içerikleriyle ilgili Soruya Öğretmen Adayları tarafindan Verilen Cevaplar.

\begin{tabular}{llcc}
\hline Tema & Kod & ÖA & ÖA(\%) \\
\hline KYOTO Protokolü & Havaya salınan gazlarla ilgili önlem & 2 & 06.45 \\
& - & 1 & 03.23 \\
\hline TEMA & Ağaçlandırma & 1 & 03.23 \\
& Çevre çalışmaları & 1 & 03.23 \\
& - & 1 & 03.23 \\
\hline Diğer & Cezai yaptırım & 1 & 03.23 \\
& Ağaçlandırma & 1 & 03.23 \\
& Uyarı ve ambargo koyma & 1 & 03.23 \\
& Greenpeace & 1 & 03.23 \\
& Hava kirliliği ölçüm istasyonları & 1 & 03.23 \\
& Dumansız hava sahası & 1 & 03.23 \\
\hline
\end{tabular}

Hava kirliliğini önlemeye yönelik ulusal ve uluslararası yaptırımlarla ilgili bu sorunun çok az öğretmen adayı tarafından cevaplandığı görülmektedir (Tablo 6). Soruya cevap veren öğretmen adaylarının ise TEMA gibi vakıf çalışmalarının yanı sıra çeşitli kampanyalardan bahsettikleri görülmektedir. Verilen cevaplar içinde yaptırım olarak görülebilecek tek örnek KYOTO Protokolü'dür. Üniversite öğrencileri ile yapılan farklı çalışmalar da bu sonucu destekler niteliktedir. (Karatekin, Kuş \& Merey, 2014; Oğuz, Çakçı \& Kavas, 2011).

Giresun'da (bulunduğunuz şehirde) hava kirliliği olup olmadığı ile ilgili soruya öğretmen adaylarının vermiş oldukları cevaplar Tablo 7'de sunulmuştur. 
Tablo 7.

Giresun'da Hava Kirliliği Olup Olmadığıile ilgili Soruya Öğretmen Adayları tarafından Verilen Cevaplar.

\begin{tabular}{llcc}
\hline Karar & Kod & ÖA & ÖA(\%) \\
\hline Evet & Kömür kullanımı & 20 & 64.52 \\
& Coğrafi yapı /yerleşim & 7 & 22.58 \\
& Duman & 7 & 22.58 \\
& Solunum güçlüğü & 6 & 19.35 \\
& Filtresiz baca & 3 & 09.68 \\
& Kalitesiz yakıt kullanımı & 3 & 09.68 \\
& Denize dökülen zararlı atıklar & 1 & 03.23 \\
& Orman tahribi & 1 & 03.23 \\
\hline Kısmen evet & Ağaçlık alan & 1 & 03.23 \\
\hline Cevap yok & Filtresiz baca & 1 & 03.23 \\
& Egzoz & 1 & 03.23 \\
\hline
\end{tabular}

Öğretmen adaylarının neredeyse hepsi Giresun ilinde hava kirliliği olduğunu ifade etmiş ve bunun nedenini daha çok kömür kullanımı (\%64.52) ve solunum güçlüğü (\%19.35) ile açıklamışlardır. Bu çalışmanın yapıldığı tarihin kış mevsime denk gelmesi ve şehirde ısınma amaçı kömür kullanımındaki artış bu cevabın verilmesinde önemli bir etken olabilir. Giresun ili şehir merkezinde kış aylarında kömür kullanımının artması nedeniyle hava kirliliğinin artması Giresun il Çevre Durum Raporu (2012)’nda da ortaya konulmuştur.

Öğretmen adaylarının \%22.58'i coğrafi yapı ve yerleşim nedeniyle hava kirliliğinin olduğunu belirtirken yine \%22.58'i de dumandan bahsetmiştir. Giresun şehri Giresun dağlarının eteklerinde deniz kıyısında olan bir şehirdir. Kış aylarında kullanılmakta olan ısınma sistemleri nedeniyle ortaya çıkan dumanın dağları aşarak çevreye yayılamaması ve kıyı tipi sebebiyle rüzgarlı olmayışı nedeniyle dumanın şehrin üstüne çökmüş görüntüsü bu açıklamaların altında yatan sebep olabilir. Giresun'a yakın ve benzer coğrafi özelliklere sahip bir şehir olan Samsun'da yapılan bir çalışmaya katılanlar da hava kirliliğinin kış günlerinde hissedildiğini; bilhassa kirli havanın zemine yığıldığı sabah vakitlerinde yoğunluğun arttığını belirtilmiştir (Şahin, 2004). Bu çalışmanın yapıldığı şehir olan Giresun'da da hava kirliliğinin dönemsel olduğu raporlarla ortaya koyulmuştur (Giresun il Çevre Durum Raporu, 2012). Ancak hiçbir öğretmen adayının dönemsel hava kirliliğine vurgu yapmadığı görülmektedir.

Giresun'da hava kirliliği varsa etkilerinin neler olduğu ile ilgili soruya öğretmen adaylarının vermiş oldukları cevaplar Tablo 8'de sunulmuştur.

Tablo 8.

Giresun'da Hava Kirliliği Varsa Etkilerinin Neler Olduğu ile ilgili Soruya Öğretmen Adayları tarafından Verilen Cevaplar.

\begin{tabular}{llcc}
\hline Tema & Kod & ÖA & ÖA(\%) \\
\hline Canlı & Sağlık & 25 & 80.65 \\
& Sosyal yaşam & 3 & 09.68 \\
& Ruh sağlığı & 1 & 03.23 \\
& Genetik bozulma & 1 & 03.23 \\
\hline \multirow{2}{*}{ Çevre } & İlim değişikliği & 1 & 03.23 \\
& Görüntü kirliliği & 1 & 03.23 \\
\hline \multirow{2}{*}{ Diğer } & Koku & 3 & 09.68 \\
& Çamaşır & 1 & 03.23 \\
\hline
\end{tabular}


Öğretmen adayları Giresun'daki olası hava kirliliğinin etkilerini daha çok canlı temasında açıklarken, bu temada da en çok sağlık (\%80.65) koduna değinmişlerdir (Tablo 8). Sağlık kodunda verilen cevaplar incelendiğinde genellikle solunum sistemiyle ilgili yaşadıkları sorunlardan bahsettikleri görülmüştür. Çeşitli çalışmalarda bireylerin hava kirliliğinin özellikle üst solunum yolları olmak üzere sağlık problemlerine yol açtığını düşündükleri görülmektedir. (Oğuz, Çakçı\& Kavas, 2011; Şahin, 2004; Önal \& Güngördü, 2008)

Daha önceki sorularda olduğu gibi öğretmen adayları, bu soruda da hava kirliliğinin ekonomik ve kültürel sonuçlardan bahsetmemişlerdir. Hava kirliliğinin sonuçlarının neler olduğu ile ilgili soruda bu soruya göre daha fazla çeşitlilikte kod çıkmış olması (Tablo 4) hava kirliliğinin sonuçlarının hepsinin öğretmen adaylarının kendilerini ve kendi çevrelerini etkilemediğine yönelik düşüncelere sahip olduklarını ortaya koymaktadır.

Hava kirliliğini önlemek ya da azaltmak için kendilerinin neler yapabilecekleriyle ilgili soruya öğretmen adaylarının vermiş oldukları cevaplar Tablo 9'da sunulmuştur.

Tablo 9.

Hava Kirliliğini Önlemek ya da Azaltmak için Kendilerinin Neler Yapabilecekleriyle ilgili Soruya Öğretmen Adayları tarafından Verilen Cevaplar.

\begin{tabular}{llcc}
\hline Tema & Kod & ÖA & ÖA(\%) \\
\hline \multirow{2}{*}{ Eğitim } & Bilinçlendirme & 14 & 45.16 \\
& Öğrenme & 2 & 06.45 \\
\hline \multirow{2}{*}{ Isınma } & Kaliteli yakıt kullanımı & 2 & 06.45 \\
& Doğalgaz kullanımı & 2 & 06.45 \\
& Fosil yakıt kullanımını azaltma & 1 & 03.23 \\
\hline Tarımsal faaliyet & Ağaçlandırma & 3 & 09.68 \\
\hline Sanayi /Ev & Filtre & 1 & 03.23 \\
\hline Devlet politikaları & Denetleme & 1 & 03.23 \\
\hline Diğer & Toplu taşıma & 6 & 19.35 \\
& Kişisel bakım & 5 & 16.13 \\
& Sigara & 1 & 03.23 \\
\hline
\end{tabular}

Öğretmen adayları hava kirliliğini önlemek için kendilerinin yapabileceklerini daha çok eğitim temasındaki bilinçlendirme kodu (\%45.16) ile açıklamışlardır (Tablo 9). Hava kirliğini önlemek için neler yapılabilir sorusunda da \%54.84 oranında bu koda değinmiş olmaları (Tablo 5), bilinçlendirme çalışmalarının bu iş için uygun olduğunu düşünenlerin hepsinin aynı zamanda kendilerinin bilinçlendirme çalışmaları yapmaya niyetli olmadığını göstermektedir. Bu durum nasıl yapacağını bilmemekten ya da gerçekten yapmaya istekli olmamaktan kaynaklanabilir. Hava kirliliğini önlemek için neler yapılabileceği ile ilgili soruda bu soruya göre daha fazla çeşitlilikte kod çıkmış olması hava kirliliğini önleyebilmek için kendilerinin yapabilecekleri konusunda öğretmen adaylarının kısıtlamaya gittiğini de göstermektedir. Bu kısıtlama özellikle devlet politikaları ile sanayi/ev temalarında ve diğer temasındaki toplu taşıma araçlarını kullanma kodlarında da ortaya çıkmaktadır.

İhtiyaç analizinde elde dilen bulgular genel olarak yorumlandığında, öğretmen adaylarının ve ilkokul öğrencilerinin hava kirliliğinin ne olduğunu açıklarken atmosfer, karbon monoksit, karbondioksit, fosil yakıt, kükürt dioksit, asit yağmurları, küresel ısınma, ozon tabakasının zarar görmesi, kloroflorokarbon gibi konu ve kavramlara ya hiç değinmedikleri ya da çok az değindikleri görülmektedir. Ayrıca hava kirliliğinin zararlı gazların oranındaki artış olduğunu ifade edebilen çok az öğretmen adayı ve öğrenci olduğu görülmektedir. Bununla birlikte, öğretmen adayları ya da öğrenciler arasında hava kirliliğini tanımlarken partiküller maddelere değinen bulunmamaktadır. Bu da hem öğretmen adaylarının hem de öğrencilerin hava kirliliğinin ne olduğunu tanımlayabilecekleri temel kavramlarla ilgili yeterli bilgilerinin olmadığını göstermektedir. 
Hem öğretmen adayları hem de öğrenciler hava kirliliğinin nedenlerini genellikle beşeri faaliyetlere dayandırmışlardır. Bu da kirliliğin kaynakları arasında, yerleşim yerlerinin bulunduğu coğrafi bölgenin yapısı ya da doğal afetler gibi doğal nedenlerin bulunabileceği fikrinin henüz oluşmadığını göstermektedir. Öğretmen adayları kişisel bakım ürünlerinin kullanımını bir kirlilik sebebi olarak görürken çok az öğrencinin bu konuya değinmiş olması bireyin kendi başına da havayı kirletebileceği konusunda öğrencilerin bir farkındalık geliştirmemiş olduğunu göstermektedir. Sigara kullanımı konusuna ise öğrencilerin değinmesi ve öğretmen adaylarının değinmemesi, sigaranın yandığında ortama saldığı gazların öğrenciler tarafından hava kirletici olarak nitelendirilmesine rağmen, öğretmen adaylarınca benzer şekilde nitelendirilmemesi ve sigaranın havayı kirletmeyen bir unsur olarak görüldüğü anlamına gelebilir. Hava kirliliğinin sonuçlarıyla ilgili her iki grupta kirliliğin zarar verdiği malzeme, ortam ya da sağlık gibi unsurlar nedeniyle ekonomik maliyeti ve heykellere, tarihi eserlere verdiği aşındırıcı etki gibi kültürel etkileri gibi sonuçlarına neredeyse hiç değinmemiştir. Hava kirliliğinin sonuçlarından en çok değinilen ise insan ve canlı sağlığı olmuştur. Bu da her iki grubun da hava kirliliğinin sonuçları ve topluma etkileri konusunda farkındalıklarının düşük olduğunu göstermektedir.

Hava kirliğini önlemek için ise her iki grup da daha çok kendilerinin yapmakta zorlanabilecekleri önlemlerden bahsetmiştir. Kişisel bakım ürünleri kullanımını azaltma ya da toplu taşıma araçlarını kullanmayı tercih etme gibi kirliliğe bireysel katkıyı azaltıcı önlemlere her iki grup tarafından da çok az değinilmiştir.

Soy tükenmesi, genetik bozulma, ekolojik denge ve iklim değişikliği gibi kodlara her iki grup tarafından çok az oranda değinilmiş olması hem canlılar hem de çevre için gelecekte önem teşkil edebilecek pek çok sorun konusunda iki grubun da farkındalıklarının düşük olduğunun göstergesi olabilir. Ayrıca öğretmen adaylarının hava kirliliği ile ilgili ulusal ve uluslararası yaptırımlarla ilgili neredeyse hiç bilgilerinin olmadığı görülmüştür.

Bütün bu sonuçlar ışığında hem öğretmen adaylarının hem de öğrencilerin hava kirliliği konusunda temel kavramlar, kirliliğin nedenleri, sonuçları ve geleceğe yansımaları ile ulusal ve uluslararası alanda konuyla ilgili yaptırımlar konusunda yeterince bilgi ve farkındalığa sahip olmadıkları, bu konulardaki eksikliklerinin giderilmesi ve farkındalıklarının arttırılması gerekliliği ortaya çıkmaktadır.

İhtiyaç analizi sonucunda ortaya çıkan sonuçlar araştırmacılar tarafından tartışılarak öğretmen adaylarında ve öğrencilerde hava kirliliği farkındalığı ile ilgili eksiklerin ortak noktaları belirlenmiş ve bu ortak noktalar "odak" olarak adlandırılmıştır. Hava kirliliği farkındalığını oluşturmak ya da artırabilmek için üzerinde durulması gereken odaklar Şekil 2'de verilmiştir.

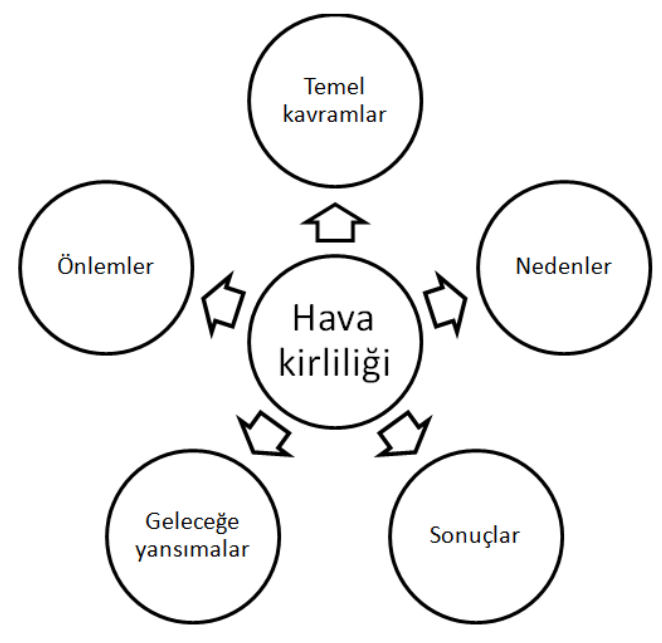

Şekil 2. Ihtiyaç analizi sonucu ortaya çıkan odaklar 
Araştırmacılar tarafından belirlenen odakların içerikleri ve farklı disiplinlerin ilkokul dördüncü sınıf öğretim programları tartışılarak, her bir odak için bir disiplin belirlenmiştir. Ardından odakların sıralanışı tartışılarak, hangi odağın hangi sırada verilmesi gerektiğine karar verilmiştir. Belirlenen sıraya göre odaklar, içerikleri ve ilişkilendirildikleri disiplinler Tablo 10’da verilmiştir.

Tablo 10.

Odaklar, içerikler ve ilgili Disiplinler.

\begin{tabular}{lll}
\hline Odak & İçerik & Disiplin \\
\hline Temel kavramlar & Hava kirliliğine ilişkin temel kavramlar & Türkçe \\
Nedenler & Hava kirliliğinin doğal ve beşeri nedenleri & Sosyal Bilimler \\
Sonuçlar & $\begin{array}{l}\text { Hava kirliliğinin canlı ve çevre bağlamında sonuçları, hava } \\
\text { kirliliğinin topluma etkileri }\end{array}$ & Fen Bilimleri \\
Gelecekteki durum & $\begin{array}{l}\text { Geçmişte ve günümüzde hava kirliliği ve bugün ki koşullara } \\
\text { göre gelecekteki durumun yordanması } \\
\text { Önlemler }\end{array}$ & Matematik \\
& $\begin{array}{l}\text { Ulusal ve uluslararası alınan önlemler ile ilgili yönetmelik, } \\
\text { antlaşar, yaptırımlar, kamu yöneticilerinin görüşleri }\end{array}$ & Kamu Yönetimi \\
\hline
\end{tabular}

Tablo 10'da görüldüğü gibi ilk olarak hava kirliliği ile ilgili temel kavramlara yönelik çalışmalarının yapılması uygun görülmüştür. Bu sebeple, atmosfer, karbon monoksit, karbondioksit, fosil yakıt, kükürt dioksit, asit yağmurları, küresel ısınma kavramları belirlenerek öğretimleri için Türkçe disiplini seçilmiştir. Hava kirliliği ile ilgili temel kavramların öğrenilmesi diğer odaklara temel oluşturmak açısından önemlidir. Temel kavramların ardından hava kirliliğinin nedenlerine yönelik farkındalığın sağlanması gerektiği düşünülmüştür. Bu odağın içeriğinde hava kirliliğine sebep olan doğal ve beşeri nedenler yer aldığından, sosyal bilimler disiplini ile ilişkilendirilmiştir. Hava kirliliğinin sonuçları odağı; hava kirliliğinin insan sağlığına etkileri, hava kirliliğinin sonuçları, bu sonuçların topluma etkilerinin canlı ve çevre bağlamında ele alınabilmesi için fen bilgisi disiplini ile ilişkilendirilmiştir. Hava kirliliğinin geçmişten günümüze durumu göz önüne bulundurulduğunda gelecekteki durumu bilmek geleceğe dair önlemler almak açısından oldukça önemlidir. Bu bağlamda hava kirliliğinin nedenleri ve sonuçları odaklarının ardından gelecekteki durumun yordanması ile ilgili farkındalık çalışmalarının yürütülmesi gerektiği düşünülmüştür. $\mathrm{Bu}$ odak geçmişe ait verilere göre geleceğe yönelik tahminleri içerdiğinden matematik disiplini ile ilişkilendirilmiştir. Son olarak ise hava kirliliğine yönelik alınan/alınabilecek önlemlerle ilgili farkındalık geliştirmek amacıyla yönetmelik, antlaşma ve yaptırımları içeren önlemler odağı ise kamu yönetimi disiplini ile ilişkilendirilmiştir. Tasarlanan içeriğin geliştirilme süreci ilerleyen bölümde ayrıntılı olarak tanıtılmıştır.

\section{Projenin Geliştirilmesi}

Projenin geliştirilmesi aşaması pilot uygulama ve pilot uygulama sonrası yapılan değişiklikler olmak üzere iki alt başlıkta açıklanmıştır.

\section{Pilot Uygulama}

Projenin geliştirilme süreci ön testlerin uygulanması, THUD’nin yürütülmesi, topluma hizmet ve son testlerin uygulanması olmak üzere dört aşamadan oluşmaktadır.

\section{Ön Testlerin Uygulanması}

Ön testlerin uygulanması aşamasında, öncelikle HKFA-II öğretmen adaylarına ve öğrencilere uygulanmıştır. Bu öğretmen adayları ve öğrenciler ihtiyaç analizine katılanlarla aynıdır. HKFA-II, araştırmacılar tarafından ihtiyaç analizi için hazırlanan HKFA'nın içeriğinin, genişletilmesiyle oluşturulan bir ankettir. Intiyaç analizinde kullanılan HKFA'nın geliştirilmesinin sebebi yapılan analiz sonrası 
öğretmen adaylarının ya da öğrencilerin hava kirliliği ile ilgili bazı konulara hiç değinmemeleridir. Bir örnek vermek gerekirse öğretmen adaylarının ve öğrencilerin doldurmuş oldukları ankette hava kirliliği nedeniyle gelecekte yaşanabilecek olumsuzluklara yönelik ifadeler kullanmadığı, günün şartlarına göre değerlendirmeler yaptığı görülmüştür. Geçmiş ve mevcut durumu göz önünde bulundurmak gelecek için yorum yapmada ve gerekli önlemlerin alınması açısından oldukça önemlidir. Bu noktada da bireylerde bu farkındalığın geliştirilmesi gerekliliği ortaya çıkmaktadır. Dolayısıyla HKFA'ya "Hava kirliliği ile ilgili önlemler alınmadığı takdirde gelecekte ne tür sorunlarla karşılaşabiliriz?" sorusu eklenmiştir. HKFA-II'de yer alan sorular ve amaçları Tablo 11'de verilmiştir.

Tablo 11.

HKFA-II'de Eklenen Sorular, Amaçları ve Sorulduğu Gruplar.

\begin{tabular}{|c|c|c|}
\hline Soru & Amaç & Grup \\
\hline Sizce hava nedir? Açıklayınız. & $\begin{array}{l}\text { Temel kavramlarla ilgili genel bakış } \\
\text { açılarını belirlemek }\end{array}$ & $\begin{array}{l}\text { Öğretmen adayları, } \\
\text { öğrenciler }\end{array}$ \\
\hline Sizce kirlilik nedir? Açıklayınız. & $\begin{array}{l}\text { Temel kavramlarla ilgili genel bakış } \\
\text { açılarını belirlemek }\end{array}$ & $\begin{array}{l}\text { Öğretmen adayları, } \\
\text { öğrenciler }\end{array}$ \\
\hline $\begin{array}{l}\text { Günlük hayatınızda hava kirliliğine } \\
\text { dair bölgesel ya da ulusal ne tür } \\
\text { etkinliklerle/faaliyetlerle } \\
\text { karşılaşıyorsunuz? Örnek vererek } \\
\text { açıklayınız. }\end{array}$ & $\begin{array}{l}\text { Hava kirliliğine yönelik önlemler ile } \\
\text { ilgili farkındalığı belirleme }\end{array}$ & $\begin{array}{l}\text { Öğretmen adayları, } \\
\text { öğrenciler }\end{array}$ \\
\hline $\begin{array}{l}\text { Hava kirliliği ile ilgili önlemler } \\
\text { alınmadığı takdirde gelecekte ne tür } \\
\text { sorunlarla karşılaşabiliriz? }\end{array}$ & $\begin{array}{l}\text { Hava kirliliğinin sonuçları ile ilgili } \\
\text { farkındalığı belirleme }\end{array}$ & $\begin{array}{l}\text { Öğretmen adayları, } \\
\text { öğrenciler }\end{array}$ \\
\hline
\end{tabular}

Ön testlerin uygulanması aşamasında, ayrıca öğretmen adaylarının uygulama öncesinde hava kirliliği ile ilgili ne bildiklerine, ne öğrenmek istediklerine ve THUD sonunda ne kazandıklarına yönelik öz değerlendirme yapmalarına fırsat sunacak Bil-iste-Öğren (BiÖ) formunun “Ne biliyorum?” ve "Ne bilmek istiyorum?" soruları uygulanmıştır. Bï̈ formu ile öğretmen adaylarının hava kirliliğiyle ilgili mevcut ve eksik bilgileri ile proje kapsamında edindikleri kazanımlara yönelik öz değerlendirmelerinin ortaya çıkarılması amaçlanmıştır.

\section{THUD’nin Yürütülmesi}

Toplamda 14 hafta süren THUD’nin -proje kapsamında tasarlanarak fakültede yürütülen dersler içinuygulama planı Tablo 12 'de verilmiştir.

Tablo 12.

THUD Kapsamında Fakültede Yürütülen Derslerin Uygulama Planı.

\begin{tabular}{cl}
\hline Hafta & Uygulama \\
\hline 1 & Ön testler ve ön araştırmalar \\
\hline 2 & $\begin{array}{l}\text { Öğretmen adayların gruplara ayrılarak, her grubun odaklarının (disiplininin) } \\
\text { belirlenmesi, odaklar ile disiplinler arası ilişkilerin araştırılması }\end{array}$ \\
\hline $3-4$ & $\begin{array}{l}\text { Grupların danışmanları rehberliğinde odaklara uygun ders planlarını } \\
\text { hazırlamaları }\end{array}$ \\
\hline 5-6-7-8-9-10-11-12 & Seminer hazırlıkları ve seminerler \\
\hline $13-14$ & Grupların değerlendirme sunumları ve son testler \\
\hline
\end{tabular}

Tablo 12'de sunulmuş olan içerik aşağıda ayrıntılı olarak açıklanmıştır:

- $\quad$ Fakültede öğretmen adaylarına ön testler (HKFA-II ve Bï̈ formu) uygulanmıştır. 
- Öğretmen adayları hava kirliliğinin ne olduğu, sebepleri, sonuçları, ulusal ve uluslararası çalışmalarla ilgili ön araştırmalar yapmışlardır.

- Gönüllülük esasına dayalı olarak oluşturulan beş grubun odakları (disiplinleri) kura usulü ile belirlenmiştir.

- Topluma hizmet için seminer hazırlıkları başlamıştır. Bu süreçte, danışmanlar (ilgili disiplin uzmanı) tarafından odakların amacı ve kapsamı gruplara tanıtıımışır.

- Danışmanlar öğretmen adaylarından gruplarının odakları ile disiplinleri arasındaki ilişkiyi araştırmalarını istemiştir.

- Grup üyeleri ve danışmanlar THUD saatleri dışında bir araya gelerek her hafta düzenli olarak çalışmaları sürdürmüşlerdir.

- Öğretmen adayları yapmış oldukları araştırmalar sonucunda odakları ile ilişkilendirebilecekleri, kendi disiplinlerinde yer alan kazanımları belirleyerek disiplinler arası ders planları geliştirmişlerdir. Bu aşamada geliştirilen etkinliklerin hava kirliliği teması için belirlenen disiplinlere ve odaklara uygun olmasına, belirlenen odak sıralamasını takip etmesine dikkat edilmiştir. Aynı zamanda bu etkinlikleri içeren seminerlerin de yeni bilgi üreterek, disiplinler arası bağlar oluşturacak interdisipliner öğretme/öğrenme ortamına uygun olmasına dikkat edilmiştir.

- Ders planlarının geliştirilmesi sürecinde de öğretmen adaylarına danışmanları rehberlik etmiştir.

- Seminer hazırlık derslerinde her hafta THUD saatinde tüm danışmanlar ve öğretmen adayları grupların çalışmalarıı odak, kapsam, disipline ait kazanım, disiplinler arası yaklaşım bağlamlarında değerlendirmiş ve öğretmen adaylarına gerekli dönütleri vermiştir. Bu dersler bütün grupların diğer disiplinler ile çalışan gruplarla çalışma, birbirlerinin çalışmalarına katkı sağlama ve kendi disiplinleri ile ilişki (bağ) kurma fırsatı sağlayarak THUD kapsamında yapılmış öğret-öğrenme faaliyetlerinin interdisipliner doğasını oluşturmuştur.

- Gruplar, diğer danışmanların ve diğer grupların geri dönütleri doğrultusunda gereken düzenlemeleri yaparak ders planlarına son hallerini vermişlerdir.

- Odak sırasına göre tamamlanan ders planları topluma hizmet amacıyla ilkokullarda seminer şeklinde uygulanmıştır. Bir odağı kapsayan ders planları ilkokullarda uygulanırken bu odağı takip eden diğer odakların seminer hazırlıkları devam etmiş̧ir.

- Topluma hizmet aşaması sonunda öğretmen adayları ilkokullarda yapmış oldukları uygulamalara ait deneyimlerini, disiplin uzmanları ve diğer gruplardaki öğretmen adayları ile paylaşmış ve sınıf tartışması ile uygulamaların eksik ve iyi yönleri belirlenmeye çalışıımıştır.

- Tüm gruplar seminerleri tamamladıktan sonra projenin hava kirliliği farkındalı̆ına yönelik katkısı olup olmadığı belirlemek amacıyla araştırmanın son aşaması olan son testlerin uygulanması aşaması gerçekleştirilmiştir. Öğretmen adaylarına son test olarak HKFA-II ve BiÖ formunun son sorusu uygulanmıştır.

\section{Topluma Hizmet}

THUD'nin topluma hizmet aşaması öğretmen adaylarının belirlenen okullarda seminerler vermesiyle gerçekleştirilmiştir. Bu okullar ve öğrenciler intiyaç analizinde belirlenen okullarla aynıdır. Bu süreç öğrencilerin okul tarafından verilen ders planlarından bağımsız olarak planlandığı ve uygulandığı için seminer olarak adlandırılsa da öğrencilerin aktif katılımının sağlandığı etkinliklerle yürütülmüştür. Bu etkinlikler yapılandırmacı yaklaşım benimsenerek hazırlanmış olan ders planlarına bağlı kalınarak çeşitli drama, deney, beyin fırtınası ve gözlem gibi teknikleri içermektedir. Seminerler gerçekleştirilirken öğretmen adaylarına gerek sınıfın öğretmeni gerek de danışmanları tarafından rehberlik yapılmamışıı. Rehberlik çalışmaları seminerlere hazırlık döneminde ve her bir seminer sonrası danışmanlar tarafından yapılmışırı. Öğretmen adayları kendi ders programlarına uygun olarak haftada iki saati bu seminerlere 
ayırabilmektedir. Bu nedenle her hafta bir okulda olmak üzere her grup seminerleri toplamda dört haftada tamamlamıştır. İlkokullarda yürütülen seminerlerin haftalara göre planı Tablo 13'de verilmiştir.

Tablo 13.

Topluma Hizmet Kapsamında Seminer Uygulama Planı.

\begin{tabular}{ccccc}
\hline \multirow{2}{*}{ Hafta } & \multicolumn{4}{c}{ ilkokul } \\
\cline { 2 - 4 } & A & B & C & D \\
\hline $1-2-3$ & Seminer hazırlıkları yürütüldüğünden herhangi bir uygulama yapılmamıştır. \\
\hline 4 & Ön test & & & \\
\hline 5 & Türkçe & Ön test & Ön test & \\
\hline 6 & Sosyal Bilimler & Türkçe & Türkçe & Ön test \\
\hline 7 & Fen Bilimleri & Sosyal Bilimler & Sosyal Bilimler & Sosyal Bilimler \\
\hline 8 & Matematik & Fen Bilimleri & Men Bilimleri & Men Bilimleri \\
\hline 9 & Kamu Yönetimi & Matematik & Kamu Yönetimi & Matematik \\
\hline 10 & Son test & Kamu Yönetimi & Son test & Kamu Yönetimi \\
\hline 11 & & Son test & Son test \\
\hline 12 & & &
\end{tabular}

Tablo 13'de görüldüğü gibi seminerler dört farklı ilkokulda gerçekleştirilmiştir. Bu okullarda rastgele seçilen ikişer şube seminer salonlarında bir araya gelerek beş hafta boyunca iki ders saati süren seminerlere katılmıştır. Ayrıca bir hafta ön bir hafta da son testler (HKFA-II) yapıldığından ilkokullardaki uygulama toplamda yedişer hafta sürmüştür.

Seminerler odaklarla bağlantılı olarak sırasıyla Türkçe, Sosyal Bilimler, Fen Bilimleri, Matematik ve Kamu Yönetim disiplinlerinde gerçekleştirilmiştir. Böylece öğretmen adayları öğrencilerle birlikte kendi disiplinleriyle ilgili çalışmalar yaparken bir yandan da gruplarının belirlenmiş olan odaklarını öğrencilere aktarmaktadır. Öğrenciler ise disiplinlerin farklılığı konusunda bilgilendirilmeden temaya ait odaklar bağlamındaki seminerlere katılmışlardır. Böylece topluma hizmet aşamasında hem öğretmen adayları hem de ilkokul öğrencileri sosyobilimsel bir konuda interdisipliner bilgi ve farkındalık kazanırken, öğretmen adayları ayrıca öğretmenlik deneyimi de kazanmıştır.

\section{Pilot Uygulama Sonrası Yapılan Değişiklikler}

Projenin geliştirilmesi kapsamında yürütülen pilot uygulama sonucunda veri toplama araçları ve öğretmen adaylarının hazırlamış olduğu ders planlarının odak/içerik/sıralama ilişkisi değerlendirilmiştir.

\section{Veri Toplama Araçlarında Yapılan Değişiklikler}

Veri toplama araçlarında yer alan soruların amaçlarına uygunluğu HKFA-II'den elde edilen verilerin içerik analiziyle belirlenmiştir. HKFA-II'nin öğrencilerin ve öğretmen adaylarının farkındalıklarının belirlenmesi amacına uygun bir veri toplama aracı olduğu tespit edilmiştir. Ancak bazı soruların düzeltilmesi bazılarının ise anketten çıkartılması gerekmiştir. Örneğin, pilot uygulama sonucunda "Televizyon, internet, dergi, gazete ve radyo gibi kitle iletişim araçlarında hava kirliliği ile ilgili nelerle karşılaşıyorsunuz?" sorusunun düzeltilmesi gerektiğine karar verilmiştir. Çünkü öğrenciler "kitle iletişim araçları' söz grubunun anlamını bilmediğinden, cevaplarında grupla iletişimden bahsetmişlerdir. Bu nedenle sorunun amacına uygun veri toplanamamıştır. Soru "kitle iletişim araçları" yerine "televizyon, gazete, internet gibi iletişim araçları" yazılarak öğrenciler için anlaşılır hale getirilmeye çalışılmıştır. "Hava kirliliği ile ilgili önlemler alınmadığı takdirde gelecekte ne tür sorunlarla karşılaşabiliriz?” sorusunda ise matematik disiplinin gelecekteki durum odağı kapsamında sağlanan farkındalık belirlenmek amaçlanmıştır. Ancak öğretmen adayları ve öğrencilerin cevapları analiz edildiğinde ortaya çıkan kodların 
“Hava kirliliğinin sonuçları nelerdir?” sorusunun kodlarıyla aynı olduğu görülmüştür. Dolayısıyla bu sorunun anketten çıkarılması gerektiğine karar verilmiştir. Pilot uygulama sonucu gerekli değişikliklerden sonra HKFA-III oluşturulmuştur. HKFA-III'de yer alan sorular Tablo 14'de verilmiştir.

Tablo 14.

HKFA-III'de Yer Alan Sorular ve Sorulduğu Gruplar.

\begin{tabular}{|c|c|c|}
\hline Soru & Amaç & Grup \\
\hline Sizce hava kirliliği nedir? Açıklayınız. & $\begin{array}{l}\text { Hava kirliliği farkındalığının genel bir } \\
\text { bakış açısıyla belirlenmesi }\end{array}$ & $\begin{array}{l}\text { Öğretmen adayları, } \\
\text { öğrenciler }\end{array}$ \\
\hline $\begin{array}{l}\text { Hava kirliliğinin nedenleri neler } \\
\text { olabilir? Açıklayınız. }\end{array}$ & $\begin{array}{l}\text { Hava kirliliğinin nedenleri ile ilgili } \\
\text { farkındalığı belirleme }\end{array}$ & $\begin{array}{l}\text { Öğretmen adayları, } \\
\text { öğrenciler }\end{array}$ \\
\hline $\begin{array}{l}\text { Hava kirliliğinin sonuçları neler } \\
\text { olabilir? Açıklayınız. }\end{array}$ & $\begin{array}{l}\text { Hava kirliliğinin sonuçları ile ilgili } \\
\text { farkındalığı belirleme }\end{array}$ & $\begin{array}{l}\text { Öğretmen adayları, } \\
\text { öğrenciler }\end{array}$ \\
\hline $\begin{array}{l}\text { Hava kirliliğini önlemek için neler } \\
\text { yapılmalıdır? }\end{array}$ & $\begin{array}{l}\text { Hava kirliliğine yönelik önlemler ile ilgili } \\
\text { farkındalığı belirleme }\end{array}$ & $\begin{array}{l}\text { Öğretmen adayları, } \\
\text { öğrenciler }\end{array}$ \\
\hline $\begin{array}{l}\text { Giresun'da hava kirliliği olduğunu } \\
\text { düşünüyor musunuz? Cevabınızı } \\
\text { sebepleriyle açıklayınız. }\end{array}$ & $\begin{array}{l}\text { Yakın çevresindeki hava kirliliği ile ilgili } \\
\text { farkındalığı belirleme }\end{array}$ & $\begin{array}{l}\text { Öğretmen adayları, } \\
\text { öğrenciler }\end{array}$ \\
\hline $\begin{array}{l}\text { Günlük hayatta hava kirliliğine dair } \\
\text { bölgesel ya da ulusal ne tür } \\
\text { etkinliklerle/faaliyetlerle } \\
\text { karşılaşıyorsunuz? Örnek vererek } \\
\text { açıklayınız. }\end{array}$ & $\begin{array}{l}\text { Hava kirliliğine yönelik önlemler ile ilgili } \\
\text { farkındalığı belirleme }\end{array}$ & $\begin{array}{l}\text { Öğretmen adayları, } \\
\text { öğrenciler }\end{array}$ \\
\hline
\end{tabular}

Tablo 14'de, projenin asıl uygulamasında her iki gruba da aynı soruların sorulduğu görülmektedir. Bu, anketin süreçteki gelişiminin bir sonucudur. Araştırmacılar tutarlılığın nasıl sağlandığını hem veri toplama sürecinde hem de verilerin analizi ve yorumlanması sürecinde açıklamalıdırlar (Yıldırım \& Şimşek, 2006). Bu çalışma için, araştırmada tutarlılığın nasıl verildiğine ilişkin açıklamalar okuyucular için net bir şekilde sunulmuştur.

Pilot uygulama sonucunda BiÖ formlarından elde edilen verilere yapılan içerik analiziyle formun öğretmen adaylarının hava kirliliği ile ilgili farkındalıklarını tespit etme amacına ulaştığı görülmüştür. BiÖ formlarında öğretmen adaylarının kendi hava kirliliği farkındalıklarıyla ilgili öz değerlendirmeler yaparken, disiplinlerarası işlenen THUD’nin mesleki deneyimlerine etkileriyle de ilgili açıklamalar yazdıkları görülmüştür. Bu bağlamda asıl uygulamada THUD kapsamında yapılan bu projenin öğretmen adaylarının öğretmenlik mesleğini icra ederken yapabilecekleri ders içi ve dersler arası etkinliklere olası yansımalarının belirlenmesi amacı ile her gruptan gönüllü öğretmen adaylarıyla görüşme yapılmasına karar verilmiştir.

Görüşme formu hazırlanırken ayrıca öğretmen adaylarının disiplinlerarası yaklaşımla yürütülen THUD kapsamında topluma hizmet etme amacının gerçekleştirilmesi ve sürecin işleyişi hakkındaki görüşlerini de belirlemek amaçlanmıştır. Yarı yapılandırılmış yüz yüze görüşme olarak tasarlanan görüşmelerde öğretmen adaylarına on soru sorulmuştur. Bu sorular şu şekildedir:

1. Yaptığınız çalışmanın amacını biliyor musunuz? Evetse nedir? Hayırsa sizce ne olabilir? Grubunuzun amacı nedir? Diğer grupların amaçlarını da biliyor musun?

2. Sizce yaptığınız çalışma amacına ulaşmış mıdır (Sınıf olarak ve grup bazında)? Neden böyle düşünüyorsunuz?

3. Bu çalışmayla topluma hizmet ettiğinizi düşünüyor musunuz? Nasıl? 
4. Bu çalışmanın uygulama sürecini düşündüğünüzde, süreçle ilgili düşünceleriniz nelerdir? Olumlu ve olumsuz olarak açıklar mısınız (Grup ve sınıf bazında)?

5. Bu çalışma disiplinlerarası bir çalışma olarak değerlendirilebilir mi? Neden?

6. Diğer grupların yaptıkları çalışmalar senin konu hakkındaki bilgi birikimine katkı sapladı mı? Ne gibi bir katkısı olduğunu grup bazında açıklar mısın?

7. Yapılan bu çalışmanın sana öğretmenlik deneyimi adına katkıları oldu mu? Nasıl?

8. Öğretmen olduğunda sınıfında disiplinlerarası bir etkinlik yapmayı düşünür müsün? Neden?

9. Bu çalışmaya öğretmen gözüyle baktığınızda sizin ilkokullarda yaptığınız öğretmenlik ile fakültedeki öğretmenlerinizin yaptıkları öğretmenlik arasında farklar var mı? Nasıl?

10. Bu çalışmaya öğrenci gözüyle baktığınızda sizin öğrencilik deneyiminizle ilkokullardaki çocukların öğrencilik deneyimi arasında farklar var mı? Nasıl?

Odak, Içerik ve Sıralamada Yapılan Değişiklikler

Pilot uygulama sırasında topluma hizmet kapsamında yürütülen seminerlere yönelik yapılan sınıf tartışmaları ve grup danışmanlarının seminer hazırlıklarında/seminerlerde yaşananlarla ilgili öğretmen adaylarından edindikleri bilgiler ışığında asıl uygulamada yapılan seminerler için disiplinlerin sırası, odakları, içerikleri ve yapılan değişimler Tablo 15'de verilmiştir.

Tablo 15.

Asıl Uygulama Kapsamında Odak, Içerik ve Disiplin ilişkisi.

\begin{tabular}{clll}
\hline U.S. & Disiplin & Odak & İçerik \\
\hline 1 & Türkçe & Temel kavramlar & Hava kirliliği ile ilgili temel kavramlar \\
2 & $\begin{array}{l}\text { Fen } \\
\text { Bilimleri }\end{array}$ & $\begin{array}{l}\text { Nedenler ve } \\
\text { sonuçlar }\end{array}$ & $\begin{array}{l}\text { Hava kirliliğinin insan sağlığına olan etkileri ve fen disiplini } \\
\text { bağlamında toplumsal ve sosyal etkileri }\end{array}$ \\
3 & $\begin{array}{l}\text { Sosyal } \\
\text { Bilimler }\end{array}$ & $\begin{array}{l}\text { Nedenler ve } \\
\text { sonuçlar } \\
\text { Hava kirliliğinin doğal ve beşeri neden ve sonuçları }\end{array}$ \\
Matematik & $\begin{array}{l}\text { Gelecekteki } \\
\text { durum }\end{array}$ & $\begin{array}{l}\text { Geçmişteki ve günümüzdeki hava kirliliği durumu ve bugün } \\
\text { ki koşullara göre gelecekteki durumun yordanması } \\
\text { Önceki grupların sunumlarını toparlama/özetleme, kanun } \\
\text { ve yönetmelikler, farklı ülkelerde yaplan uygulamalar } \\
\text { toplumun görüşleri }\end{array}$ \\
\hline
\end{tabular}

U.S.: Uygulama sırası

Pilot uygulamadaki odaklardan farklı olarak asıl uygulamada nedenler ve sonuçlar olmak üzere iki odağın birleşerek nedenler ve sonuçlar olmasına karar verilmiştir (Tablo 15). Hava kirliliğinin beşeri ve doğal nedenleri, sonuçlarından bağımsız verilemeyeceği için fen bilimleri ve sosyal bilimler disiplinlerinin hava kirliliğinin nedenlerini ve sonuçlarını kendi disiplinleri bağlamında ele alınmasına karar verilmiştir. Bununla birlikte fen bilimleri grubu hava kirliliğinin beşeri nedenleri ve sonuçlarına değinirken, sosyal bilimler grubu da hava kirliliğinin doğal ve beşeri nedenleri ile birlikte sonuçlarına da değinmiştir.

Kamu yönetimi grubundaki öğretmen adayları pilot uygulamadaki ders planlarında kamu görevlileri ile yaptıkları görüşmelerden faydalanmışlardır. Ancak bu süreçte çeşitli sorunlarla karşılaştıklarından asıl uygulamadaki öğretmen adayları kamu görevlilerinin görüşleri yerine vatandaşların görüşlerinden faydalanmışlardır. Ayrıca yine pilot çalışmadan farklı olarak farklı ülkelerdeki hava kirliliğine yönelik uygulamalara da ders planlarında yer verilmiştir.

Bunlara ek olarak asıl uygulamada odakların disiplinlerle bağlantılarının net olarak anlaşılabilmesi için öğretmen adaylarının hazırlamış oldukları ders planlarına ilkokul 4. Sınıf öğretim programındaki kazanımlarla eşleştirmeleri istenmiştir. Ayrıca ders planlarının öğretmen adaylarının daha önceden bildiği $5 \mathrm{E}$ öğretme/öğrenme modeline uygun olarak hazırlanmasına karar verilmiştir. 


\section{Asıl Uygulama}

Projenin asıl uygulama süreci, Şekil 1'deki pilot uygulamayla örtüşecek bir sıralamayla ön testlerin uygulanması, THUD’nin yürütülmesi, topluma hizmet ve son testlerin uygulanması aşamaları takip edilerek gerçekleştirilmiştir. Birinci aşamada öğretmen adaylarına HKFA-III ve Bï̈ formu ön test olarak uygulanmıştır. Asıl uygulamaya katılan öğretmen adayları bir eğitim fakültesinde sınıf öğretmenliği öğrencisi olup THUD’ni alan dört gruptan kura ile belirlenmiştir. Öğrenciler ise öğretmen adaylarının topluma hizmet sürecinde ulaşabilmeleri için aynı ildeki ilkokullardan kura ile seçilen üç okuldan yine kura ile seçilen ikişer sınıfa devam eden toplamda 122 dördüncü sınıf öğrencisidir.

THUD’nin yürütüldüğü ikinci aşama ise pilot uygulamadaki gibi (Tablo 12) gerçekleştirilmiştir. Gruplar Tablo $15^{\prime}$ de sunulan odak, disiplin ve içeriğe uygun ders planlarını hazırlamak için danışmanlarıyla çalışmalarını yürütmüştür. Asıl uygulamadaki disiplin-kazanım ilişkileri Tablo $16^{\prime}$ da sunulmuştur.

Tablo 16.

Asıl Uygulamada Disiplinler ve Kazanımlar.

\begin{tabular}{ll}
\hline Disiplin & Öğretim programlarındaki kazanımlar \\
\hline Türkçe & Dinledikleri ile ilgili çıkarımlar yapar. \\
& Dinlediklerine ilişkin karşılaştırmalar yapar. \\
& Bilmediği kelimelerin anlamlarını araştırır. \\
& Dinlediklerini başkalarıyla paylaşır. \\
& Görsellerden yararlanarak söz varlığını geliştirir. \\
& Dinlediklerinde geçen bilmediği kelimelerin anlamlarını tahmin eder (Milli Eğitim \\
& Bakanlığı [MEB], 2009a). \\
\hline Fen Bilimleri & İnsan ve çevre arasındaki karşılıklı etkileşimin önemini kavrar. \\
& Çevre kirliliğini önlemek için yakın çevresini temiz tutar (MEB, 2013). \\
\hline Sosyal Bilimler & Çevresinde gördüğü doğal ve beşeri unsurları ayırt eder (MEB, 2005). \\
\hline Matematik & Sütun grafiğini oluşturur. \\
& Sütun grafiğini yorumlar (MEB, 2009b). \\
\hline Kamu yönetimi & Hava kirliliği ile ilgili kanun ve yönetmelikleri inceler. \\
& Hava kirliliği ile kamu ve ilgili kamu görevlilerinin görüşlerini merak eder. \\
\hline
\end{tabular}

Tablo 16’dan görüldüğü gibi Türkçe ve matematik disiplinlerinde kazanımlar disipline özgü olarak yazılmış olmasına rağmen, fen ve sosyal bilimler disiplinlerinde kazanımlar çevre bağlamında yazılmıştır. Bu durum fen ve sosyal bilimler disiplinlerinin öğretim programlarının çevre eğitimine yönelik kazanımlar içermesinden kaynaklanmaktadır. Kamu Yönetimi disiplini ise ilkokullarda bir ders olarak var olmadığı için ilgili grup danışmanı tarafından belirlenmiş olan kazanımlar diğer danışmanlarla birlikte incelenerek karara bağlanmıştır.

Topluma hizmetin gerçekleştirildiği üçüncü aşamada seminerler ise Tablo 15'deki gibi yürütülmüştür. Seminerlerde her bir grubun ilkokullarda sundukları ders planları şu şekilde özetlenebilir:

- Türkçe: Hava kirliliğinde temel kavramlar ile ilgili dramanın izlenmesi, dinlediklerinde geçen bilmediği kelimelerin anlamlarının tahmin edilmesi, dinlenilenler ile çıkarımlar ve karşılaştırılmalar yapılması, temel kavramlara yönelik görsellerin incelenmesi ve görsellerden yararlanılarak söz 
varlığının geliştirilmesi, temel kavramlara yönelik bulmacaların çözülmeye çalışılması bu süreçte bilinmeyen kelimelerin anlamlarının araştırılması

- Fen Bilimleri: Hava kirliliğinin gözlenmesi için deney yapılması, deneyin sonucunun canlı sağlı̆ı üzerine etkilerin, hava kirliliğinin beşeri neden ve sonuçlarıyla birlikte tartışılması, konu ile ilgili animasyonların izlenmesi ve tartışılması ile insan ve çevre arasındaki karşlıklı etkileşimin öneminin farkına varılması.

- Sosyal Bilimler: Hava kirliliğinin neden ve sonuçlarına ilişkin doğal ve beşeri unsurlarla ilgili drama ve görsel materyallere yer verilerek hava kirliliğinin doğal ve beşeri neden ve sonuçlarının açıklanması.

- Matematik: Şehrimizin geçmiş yıllardaki hava kirliliğine yönelik verilerinin araştırılması, verilere yönelik sütun grafiklerinin oluşturulması ve yorumlanması, grafik yardımıyla gelecekteki durumu belirlemeye yönelik problemlerin çözülmesi.

- Kamu yönetimi: Hava kirliliğinin önlemesine yönelik ulusal kanun ve yönetmeliklere, uluslararası anlaşmalara, farklı ülkelerdeki hava kirliliği durumlarının karşılaştııımasına yönelik dramaların izlenmesi, toplumun görüşlerine yönelik yapılan röportajların izlenmesi ve tartışılması.

Son olarak, öğretmen adaylarına HKFA-III ve Biö formu son test olarak uygulanmıştır. Ayrıca her gruptan rastgele seçilen iki öğretmen adayıyla görüşmeler yapılarak asıl uygulama tamamlanmıştır.

\section{Sonuç ve Öneriler}

Bu proje kapsamında sınıf öğretmenliği bölümü altıncı dönem öğrencilerine yönelik THUD için disiplinlerarası bir öğretme/öğrenme ortamı tasarlanmıştır. Öğretme/öğrenme ortamının bir bölümü fakültede yapılan etkinlikler bir kısmı ise ilkokullarda yapılan etkinliklerden oluşmaktadır.

Hava kirliliği temasında gerçekleştirilen bu etkinliklerin fakültede yapılan çalışmalarda, ilkokul öğrencilerine yönelik hava kirliliğini açıklamak için kullanılabilecek odaklarda beş farklı disiplinde ders planlarının hazırlanması yer almaktadır. Bu disiplinler ana dil olarak Türkçe, Sosyal Bilimler, Fen Bilimleri, Matematik ve Kamu Yönetimidir. Her bir disiplinde görevli öğretmen adayları kendi konu alanıyla bağlantılı olacak şekilde sırasıyla hava kirliliği ile ilgili temel kavramlar, nedenler ve sonuçlar, gelecekteki durum ile önlemler odakları üzerinde çalışmalar yapmışlardır. Oluşturulmuş olan odak/disiplin grupları fakülte içinde yapılan paylaşımlarla sadece kendileri öğrenmekle kalmamış aynı zaman da birbirilerinden de öğrenme şansını elde etmişlerdir. Dolayısıyla bir disiplin grubundaki öğretmen adayı, diğer gruplardaki öğretmen adaylarının hava kirliliği ile ilgili yapmış oldukları çalışmaları inceleme ve değerlendirme sürecine katılma fırsatı bulmuştur. Böylece öğretmen adayları hava kirliliği konusunu disiplinlerarası bir bakış açısıla inceleme şansı elde etmişlerdir. Bunun yansıra hem sosyobilimsel sorunlarla ilgili hem de disiplinlerarası öğrenme ortamları için ders planları hazırlama konusunda deneyim kazanmışlardır.

Etkinliklerin ilkokullarda yürütülen kısmında ise öğretmen adayları hazırlamış oldukları ders planlarını uygulamaya geçirerek farklı ilkokullarda sunumlar yapmışlardır. Böylece sadece öğretmen adayları değil, aynı zamanda ilkokul öğrencileri de hava kirliliği ile ilgili disiplinlerarası bilgi ve farkındalık kazanmışlardır. Bunun yanı sıra öğretmen adayları disiplinlerarası ilişkilendirmelerin nasıl yapılabileceği konusunda deneyim kazanmışlardır.

THUD kapsamında gerçekleştirilebilecek bu tip projeler ile öğretmen adayları hem toplumsal bir sorunla ilgili farkındalık kazanacak, hem de kendi mesleki bilgilerini kullanma ve geliştirme imkânı bulacaktır. Araştırma sonuçlarının katılımcıların hava kirliliği farkındalığında artış olduğunu ortaya koyması halinde THUD kapsamında benzer etkinlikler geliştirilerek, sosyobilimsel konularda öğrencilere ve topluma farkındalık kazandırma çalışmaları yapılabilir. Bu projenin sonuçlarının THUD'de danışmanlık 
yapan öğretim üyeleri ve kendi okullarında topluma hizmet uygulamaları yapmayı planlayan öğretmenler tarafından içeriğin disiplinlerarası olarak planlanması konusunda örnek olarak kullanılabileceği düşünülmektedir. Böylece öğretmen adaylarına ya da öğrencilere bir konuyu tek bir disiplinle sınırlandırılmış bir şekilde değil, gerçek hayatta olduğu gibi aynı anda pek çok disiplin açısından analiz etme ve değerlendirme fırsatı sunulabilir.

\section{Teşekkür ve Bilgilendirme}

Bu çalışma Giresun Üniversitesi Bilimsel Araştırma Projeleri Birimi tarafından desteklenmiştir (Proje numarası: BAP-A-250414-33, 2014). Ayrıca çalışma 2015 yılında gerçekleştirilen International In-Service Programme and Symposium'da sunulmuş "Interdisciplinary Community Service Practices In Teacher Training: Air Pollution Awareness" başlıklı bildirinin genişletilmiş halidir. 


\section{References}

Arcagök, S. \& Şahin, Ç. (2013). Teacher trainers and pre service teachers views of service learning course. Ondokuz Mayıs University Journal of Faculty of Education, 32(2), 21-54.

Barton, A. (2000). Crafting multicultural science education with pre-service teachers through servicelearning. Journal of Curriculum Studies, 32, 797-820.

Beldağ, A., Yaylacı, A.F., Gök E.,\& İpek, C. (2015). Evaluation of community service practices course in terms of university-society cooperation. Journal of Kırşehir Education Faculty, 16(2), 161-178.

Boyes, E., Stanisstreet, M., \& Yeung, S.P. (2004). Air pollution: The knowledge and attitudes of secondary school students in Hong Kong. International Research in Geographical \& Environmental Education, 13(1), 21-37.

Council of Higher Education (CoHE) (2006). Eğitim fakültelerinde uygulanacak yeni programlar hakkında açıklama. [Statements about the new programs to be implemented in the faculties of education]. Retrieved May 16, 2016 from

https://www.yok.gov.tr/documents/10279/49665/aciklama programlar/aa7bd091-9328-4df7aafa-2b99edb6872f

Çetin, T.,\& Sönmez, Ö.F. (2009). The evaluation of the opinions of social sciences teacher candidates about the practices in social services lesson in terms of aims and contents. Gazi University Journal of Gazi Educational Faculty, 29(3), 851-875.

Darçın, E.S., \&Sert-Çıbık, A. (2009). Examining elementary second grade students' knowledge levels about air pollution according to their socioeconomic situations. The Journal of SAU Education Faculty, 17, 183-204.

Demirbaş, M., \& Pektaş, H.M. (2009). Elementary students' levels of realization of basic concepts related with environment problem. Necatibey Faculty of Education Electronic Journal of Science and Mathematics Education, 3(2), 195-211.

Demirkaya, H. (2006). Çevre eğitiminin Türkiye'deki coğrafya programları içerisindeki yeri ve çevre eğitimine yönelik yeni yaklaşımlar. [The place of environmental education in geography curricula in Turkey and new approaches to environmental education]. Journal of Social Sciences [Firat University], 16(1), 207-222.

Drake, S., \& Burns, R. (2004). Meeting standards through integrated curriculum. Association for Supervision and Curriculum Development (ASCD). Retrieved September 1, 2015 from http://www.ascd.org/publications/books/103011/chapters/What-Is-Integratedcurriculum\%C2\%A2.aspx

Ekşi, Z., \&Cinoğlu, M. (2012). Topluma hizmet uygulamalarının değerlendirilmesi. [Evaluation of community service practices]. Celal Bayar University The Journal of Social Sciences,10(2), 3-22.

Fogarty, R. (1991). Ten ways to integrate curriculum. Educational Leadership, 49(2), 61-65.

Giles, D. E., \& Eyler, J. (1994). The theoretical roots of service learning in John Dewey: towards a theory of service learning. Michigan Journal of Community Service Learning, 1, 77-85.

Giresun City Environmental Status Report (2012). Retrived November 15, 2015from http://www.csb.gov.tr/turkce/dosya/ced/icdr2011/giresun icdr2011.pdf

Gökçe, N. (2011). Sosyal bilgiler öğretmen adaylarının topluma hizmet uygulamalarına ilişkin değerlendirmeleri. [Social studies teacher candidates' opinions about thepractice of community service]. International Journal of Human Sciences, 8(2), 176-194.

Gökçe, N. (2012). Sosyal bilgiler eğitiminde topluma hizmet uygulamaları. [Community service practices in social studies education]. In: M. Safran (Ed.), Sosyal Bilgiler Öğretimi (pp. 586-606). Ankara: Pegem Akademi.

Grady, J.B. (1994). Interdisciplinary Curriculum: A Fusion of Reform Ideas. Retrieved July 13, 2015 from http://files.eric.ed.gov/fulltext/ED375980.pdf

Güllü, G. (2013). Indoor air quality studies in Turkey. Hava Kirliliği Araştırmaları Dergisi, 2, 146-158.

Güney, E. (2004). Çevre Sorunları Coğrafyası [Environmental Issues Geography]. Ankara: Gündüz eğitim ve yayıncılık. 
İşler, A.Ş. (2004). Sanat eğitiminde disiplinlerarası tematik yaklaşım. [Interdisciplinary thematic approach in art education]. Milli Eğitim Dergisi, 163, 43-54.

Jacobs, H.H. (1989).Design options for an Integrated curriculum. In: Jacobs, H.H. (Ed.). Interdisciplinary curriculum: Design and implementation (pp. 12-24). Association for Supervision and Curriculum Development (ASCD). Retrieved October 4, 2015from http://files.eric.ed.gov/fulltext/ED316506.pdf

Karatekin, K., Kuş, Z., \& Merey, Z. (2014). Social studies pre-service teachers' social participation in solutions to environmental problems. Elementary Education Online,13(2), 345-361.

Kesten, A. (2012). The evaluation of community service-learning course in terms of prospective teachers' and instructors' opinions. Educational Sciences Theory and Practice, 12(3), 2125-2148.

Köklükaya, A.N.,\& Yildirim, E.G. (2016). Pre-service teachers' perceptions towards the ozone layer depletion and acid rain. Bartin University Journal of Faculty of Education, 5(1), 154-168.

Küçükoğlu, A. (2012). Öğretmen eğitiminde topluma hizmet uygulamaları deneyimsel bir öğrenme yaklaşımı. [Community service-learning in teacher education: an experimental learning approach].International Journal of Turkish Literature Culture Education,1(4), 214-226.

Küçükoğlu, A., Korkmaz, Z. S., Köse, E., \& Taşgın, A. (2014). Öğretmen adaylarının topluma hizmet uygulamaları dersine ilişkin görüşleri üzerine bir inceleme. [An analysis on preservice teachers' views about community service- learning]. International Journal of Eurasia Social Sciences, 5(17), $1-26$.

Lederman, N. G., \& Niess, M. L. (1997). Integrated, interdisciplinary, or thematic instruction? Is this a question or is it quastionable semantics? School Science and Mathematics, 97(2), 57-58.

Ministry of National Education (MoNE), (2005). Ilköğretim 4.-5. sınıflar sosyal bilgiler dersi öğretim programı [Elemantary School Social Studies Curriculum (4-5th grades)]. Ankara, Turkey: Milli Eğitim Bakanlığı.

Ministry of National Education (MoNE), (2009a). ilköğretim Türkçe Öğretim Programı. (1, 2, 3, 4, 5. Sınıflar) [Primary School Turkish Curriculum (1, 2, 3, 4, 5. grades)]. Ankara, Turkey: Milli Eğitim Bakanlığı.

Ministry of National Education (MoNE), (2009b). Ilköğretim Matematik Dersi 1-5. Sınıflar Öğretim Programı [Elemenatry School Mathematics Curriculum (1-5th grades)]. Ankara, Turkey: Milli Eğitim Bakanlı̆̆ı.

Ministry of National Education (MoNE), (2013). Ilköğretim Kurumları (ilkokullar ve Ortaokullar) Fen Bilimleri Dersi (3, 4, 5, 6, 7 ve 8. Sınıflar)Öğretim Programı [Elemantary School(Primary and Secondary) Science Curriculum (3, 4, 5, 6, 7 and 8th grades)]. Ankara, Turkey: Milli Eğitim Bakanlığı.

Oğuz, D., Çakcı, I., \& Kavas, S. (2011). Environmental awareness of students in higher education. Turkish Journal of Forestry, 12(1), 34-39.

Önal, H.,\& Güngördü, E. (2008).Active learning application of geography teaching (A simple of air pollution). The Journal of Social Sciences Enstitute [Balıkesir University], 11(19), 60-74.

Özdemir, S.M., \& Tokcan, H., (2010). Topluma hizmet uygulamaları dersinin öğretmen adaylarının görüşlerine göre değerlendirilmesi. [Evaluation of community service course according to preservice teachers' views]. The Journal of Ahmet Keleşoğlu Education Faculty, 30, 41-61.

Özey, R. (2009). Çevre sorunları [Environmental issues]. İstanbul: Aktif Yayınevi.

Öztürk, K. (2002). Global climatic changes and their probable effect upon Turkey. Gazi University Journal of Gazi Educational Faculty, 22(1), 47-65.

Petrie, H. (1992). Interdisciplinary education: Are we faced with insurmountable opportunities? Review of Research in Education, 18, 299-333.

Sadık F., Çakan H., \& Artut K. (2009). Perceptions about environmental problems in elementary school children's drawings. The 10th European Affective Education Network Conference, University of the West of Scotland, UK.

Seçgin, F., Yalvaç, G.,\& Çetin, T. (2010). Ilköğretim 8. sınıf öğrencilerinin karikatürler aracılığıyla çevre sorunlarına ilişkin algıları [8th grade students' perceptions regarding environmental issues 
through cartoons]. In International Conference on New Trends in Education and Their Implications (p.391-398). Antalya, Turkey.

Selvi, M., \& Yıldız, K. (2009). Biyoloji öğretmeni adaylarının sera etkisi ile ilgili algılamaları. [ıdentify preservice biology teachers' perception about the concept of greenhouse effect]. Türk Eğitim Bilimleri Dergisi, 7(4), 813-852.

Smith, K.A. (2006). The effect of an integrated high school science curriculum on student achievement, knowledge retention, and science attitudes. Unpublished doctoral dissertation, University of Missouri, Kansas City.

Sönmez, Ö.F. (2010). Sosyal bilgiler öğretmen adaylarının topluma hizmet uygulamaları dersine yönelik görüşlerinin kazanım boyutunda değerlendirilmesi. [The evaluation of the ideas in the aspect of acaustion of social studies preservice terachers on the lecture of practice of the service to the public]. The Black Sea Journal of Social Sciences, 2(2), 53-72.

Şahin, E. (2013). Predictors of Turkish elementary teacher candidates' energy conservation behaviors: An approach on value-belief-norm theory. International Journal of Environmental \& Science Education, 8, 269-283.

Şahin, E., Ertepınar, H., \& Teksöz, G. (2012). University students' behaviors pertaining to sustainability: A structural equation model with sustainability-related attributes. International Journal of Environmental and Science Education, 7, 459-478.

Şahin, K. (2004). People's views to air pollution in Samsun. Ekoloji, 13(51), 7-12.

Şahin, N.F., Cerrah, L., Saka, A., \& Şahin, B. (2004). A practice for student centered ecology course in higher education. Gazi University Journal of Gazi Educational Faculty, 24(3), 113-128.

Thornber, J., Stanisstreet, M.,\& Boyes, E. (1999). School students' ideas about air pollution: Hindrance or help for learning? Journal of Science Education and Technology, 8(1), 67-73.

Topçu, M.S., 2015. Sosyobilimsel konular ve öğretimi. [Socioscientific issues and instruction]. Ankara: Pegem Akademi.

Tress, B., Tress, G., \& Fry, G. (2005). Researchers' experiences, positive and negative, in integrative landscape projects. Environmental Management, 36(6), 792-807.

Tress, G., Tress, B., \& Fry, G. (2006). Publishing integrative landscape research: Analysis of editorial policies of peer-reviewed journals. Environmental Science \& Policy, 9(5), 466-475.

Tress, G., Tress, B., \&Fry, G. (2007). Analysis of the barriers to integration in landscape research projects. Land Use Policy, 24(2), 374-385.

URL-1 http://education.nationalgeographic.com/education/encyclopedia/air-pollution/?ar a=1(29 March 2016).

URL-2 http://www.who.int/mediacentre/news/releases/2014/air-pollution/en/(29 March 2016).

URL-3 http://cevresagligi.thsk.saglik.gov.tr/bilgi-dokumanlar/halk-sagligina-yonelik/992-havakirlili\%C4\%9Fi-ve-sa\%C4\%9Fl\%C4\%B1k-etkileri.html(29 March 2016).

Uzgören, E., \& Yücel, Ö. (1999). Çevre sorunları bağlamında dışsal ekonomiler ve ekonomik etkilerinin analizi. [External economies and analysis of economic impacts in the context of environmental issues]. Dumlupınar University Journal of Social Sciences, 3, 97-110.

Yıldırım, A., \& Şimşek, H. (2006). Sosyal bilimlerde nitel araştırma yöntemleri [Qualitative research methods in social sciences]. Ankara: Seçkin Yayıncılık.

Yılmaz, A., Morgil, ì., Aktuğ, P.,\& Göbekli, İ. (2002). Ortaöğretim ve üniversite öğrencilerin, çevre, çevre kavramları ve sorunları konusundaki bilgileri ve öneriler. [Knowledge of the secondary school and university students on the environment, environmental concepts and problems and suggestions]. Hacettepe University Journal of Education, 22, 156-162.

Yılmaz, K. (2011). Eğitim fakültelerinin sosyal sorumluluğu ve topluma hizmet uygulamaları dersi: Nitel bir araştırma. [Social responsibility of education faculties and the lessons of community service practices: A qualitative study].Journal of Theoretical Educational Sciences, 4(2), 86-108.

You, Z., \& Rud, A.G. (2010). A model of Dewey's moral imagination for service learning: Theoretical explorations and implications for practice in higher education. Education \& Culture, 26(2), 36-51. 